\title{
Tocotrienol is a cardioprotective agent against ageing-associated cardiovascular disease and its associated morbidities
}

\author{
Nardev Ramanathan ${ }^{1,2^{*}}$, Esther $\operatorname{Tan}^{3}$, Li Jun Loh ${ }^{3}$, Boon Seng Soh ${ }^{3,4,5}$ and Wei Ney Yap ${ }^{1,2}$
}

\begin{abstract}
Ageing is a nonmodifiable risk factor that is linked to increased likelihood of cardiovascular morbidities. Whilst many pharmacological interventions currently exist to treat many of these disorders such as statins for hypercholesterolemia or beta-blockers for hypertension, the elderly appear to present a greater likelihood of suffering non-related side effects such as increased risk of developing new onset type 2 diabetes (NODM). In some cases, lower efficacy in the elderly have also been reported. Alternative forms of treatment have been sought to address these issues, and there has been a growing interest in looking at herbal remedies or plant-based natural compounds. Oxidative stress and inflammation are implicated in the manifestation of ageing-related cardiovascular disease. Thus, it is natural that a compound that possesses both antioxidative and anti-inflammatory bioactivities would be considered. This review article examines the potential of tocotrienols, a class of Vitamin $\mathrm{E}$ compounds with proven superior antioxidative and anti-inflammatory activity compared to tocopherols (the other class of Vitamin E compounds), in ameliorating ageing-related cardiovascular diseases and its associated morbidities. In particular, the potential of tocotrienols in improving inflammaging, dyslipidemia and mitochondrial dysfunction in ageing-related cardiovascular diseases are discussed.
\end{abstract}

Keywords: Cardiovascular disease (CVD), Ageing, Tocotrienols, Tocotrienol-rich fraction (TRF), a-tocopherol, Inflammation, Inflammaging, Oxidative stress, Atherosclerosis, Reactive oxygen species (ROS)

\section{Background}

Cardiovascular disease (CVD) is the number one cause of mortality globally according to the World Health Organisation (WHO). By 2030, approximately 30 million individuals are expected to die from CVD every year [1]. While recent changes in dietary habits and lifestyle are often discussed as a major contributing factor for this phenomenon, ageing presents another fertile ground for lowering the threshold required for the manifestation of the disease.

While the exact mechanics of ageing is still subject to active research, a couple of theories currently prevail as the leading theories that might explain, at least in part, the pathophysiological aspects of ageing. These are the free radical theory and the inflammaging theories of

\footnotetext{
* Correspondence: nardevr@gmail.com

'Department of R\&D, Davos Life Science Pte Ltd, 3 Biopolis Drive, \#04-19, Davos 138623, Singapore

2Department of R\&D, Level 8, Menara KLK 1,Jalan Pju 7/6,Mutiara Damansara, 47810, 47800 Petaling Jaya, Selangor, Malaysia

Full list of author information is available at the end of the article
}

ageing $[2,3]$. The former purports that with ageing, even in healthy ageing, there is a higher risk of oxidative stress build-up within the mitochondria, which eventually leads to a vicious cycle that leads to further damaged mitochondria and increased free radicals [2]. This increased oxidative stress is a risk factor for the development of chronic diseases such as cancer and diabetes. Inflammaging, on the other hand, refers to the chronic low grade inflammation that persists and leads to chronic disease [4]. These are also discussed in more detail throughout the review.

From a cardiovascular health point of view, ageing can thus be viewed as a combination of deteriorating cardiovascular protection mechanisms and a concomitant increase in disease processes that greatly increases the development of heart failure. Half of all heart failure diagnoses and 9 out of 10 of all heart failure deaths occur in the segment of the population over age 70 [5]. Hence, it would not be an overstatement to say that heart failure is a major risk for the elderly. 
Many pharmaceutical interventions exist such as statins and beta blockers, but, as will be described later, many of these can have adverse events, especially in the elderly, whose physiologies are much more susceptible to certain types of pharmaceutical intervention [6-8]. There has recently been a growing interest in exploring treatment using naturally occurring compounds. While there has been scepticism about the efficacy of these compounds [9-11], in often cases, the irregular efficacies reported are due to the complex and inconsistent preparation of these herbal remedies [12]. With an increased scrutiny on manufacturing and regulatory practices in the nutraceutical industry worldwide, there has been a growing acceptance of nutrition in both consumer healthcare space and clinical settings as a bona fide interventional strategy in combating all types of human disease [12-14].

In particular, nutritional strategies have been reported to effectively lower the risk of the toxicity caused by reactive oxygen species (ROS) and hence improve in vivo antioxidant status which is important in preventing not just cardiovascular disease but many other human diseases such as cancer, neurodegeneration and diabetes as well $[15,16]$.

\section{Tocotrienol}

The Vitamin E family consists of tocopherols and tocotrienols, with each of the two groups consisting of 4 different homologues each $(\alpha, \beta, \gamma$ and $\delta)$. Structurally, tocopherols and tocotrienols share the identical chromanol head and only differ by the degree of saturation of hydrophobic tridecyl chain. Tocopherols have saturated phytyl tails whereas tocotrienols have unsaturated isoprenoid side chain with three double bonds. The isomers differ from each other by the attachment of different Rgroups on the chromanol head (Fig. 1) [17].

Vitamin E has traditionally been associated with tocopherols only. Tocopherols were discovered nearly a century ago, in 1922 by Evans and Bishop [18] and enjoyed a dominant and lengthy period in the limelight. Tocopherols are found in most vegetable oils, nuts, seeds and whole grains [19].

Tocotrienols on the other hand is a more recent discovery. Qureshi and colleagues first differentiated tocotrienols and its properties from tocopherols in 1986 [20]. In the years that followed, several groups identified palm (Elaeis guineensis) oil as a rich source of tocotrienols Approximately $75 \%$ of the Vitamin E from palm oil consists of tocotrienols [21]. Another source of tocotrienols is found in the bright red seeds of Bixa orellana, from the achiote tree, a plant native to South America. Its seeds contain a unique composition of $90 \% \delta$ tocotrienol and $10 \% \gamma$-tocotrienol, without any tocopherols in them [17, 22, 23].

The discovery of more Vitamin E compounds may seem as merely an academic pursuit, especially given the highly similar structural makeup of tocotrienols and tocopherols (Fig. 1). However, the discovery that tocotrienols may possess as much 40-60 times more antioxidative activity than tocopherols captured the attention of many [24, 25]. Further studies also suggested that tocotrienols also exhibit potent anti-inflammatory properties, a property that is only very weakly, if at all, observed in tocopherols [26-28]. In particular, tocotrienols have been shown to inhibit pathways that involve nuclear factor $\kappa B(N F-\kappa B)$ [29], Signal transducers and activators 3 (STAT3) [30] and cyclo-oxygenase 2 (COX2) [31], which are critical pathways that trigger pathological inflammatory responses.

As it became clearer that tocotrienols could be a much more bioactive form of Vitamin E compared to tocopherols, much interest in the therapeutic applications of tocotrienols arose. Chandan Sen and colleagues, for example, published many seminal papers on the potency of tocotrienols in being neuroprotective against stroke [3235]. We and others have shown the potency of the gamma/delta tocotrienol isomers in ameliorating cardiovascular and metabolic disease [36-38].<smiles>[R]c1c(C)c2c(c([R])c1O)CCC(C)(CCCC(C)CCCC(C)CCCC(C)C)O2</smiles>

$\alpha: R^{\prime}=\mathrm{CH}_{3}, \mathrm{R}^{\prime \prime}=\mathrm{CH}_{3}$

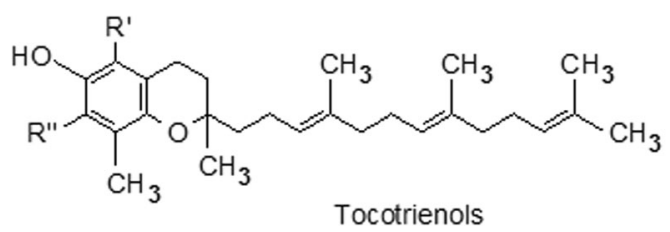

$\beta: \mathrm{R}^{\prime}=\mathrm{CH}_{3}, \mathrm{R}^{\prime \prime}=\mathrm{H}$

$\gamma: \mathrm{R}^{\prime}=\mathrm{H}, \mathrm{R}^{\prime \prime}=\mathrm{CH}_{3}$

$\delta: R^{\prime}=H, R^{\prime \prime}=H$

Tocotrienols

Fig. 1 Structural configuration of tocotrienols and tocopherols. Adapted from http://lipidlibrary.aocs.org/Analysis/content.cfm?ltemNumber=40389 
Palm tocotrienol-rich fraction (TRF) has been granted the GRAS (Generally Regarded as Safe) status by the US FDA in 2010, indicating that these compounds are safe for human consumption [39]. Clinical trials done in humans at approximately $50-400 \mathrm{mg} /$ day (equivalent to up to $6.7 \mathrm{mg} / \mathrm{kg}$ for a $60 \mathrm{~kg}$ human) for periods of 2 weeks to 18 months have not been reported to cause adverse effects [17], even in the elderly [40]. Tocotrienols has been shown to be cardioprotective in numerous cell culture, animal model and human studies [17, 38, 41, 42] (Table 1). With the increase in life expectancy of the world population in general, driven by improvements in medical science and healthcare technologies, leading causes of disability-adjusted life years (DALYs) predicted by one study was aging related heart disease [43]. It is thus critical to find ways to remedy cardiovascular ageing with safe and effective interventional strategies. In this review article, we discuss the potential of tocotrienols in combating ageing related cardiovascular diseases.

\section{Cardiovascular changes that occur with ageing}

Most of the major cardiovascular changes that take place during cardiovascular ageing could be categorised into one or more of the following:
A. Structural changes
B. Functional changes
C. Indirect changes

D. Decreased capacity to handle oxidative stress

\section{A) Structural changes}

The most evident structural cardiac change during ageing is the increase in myocardial thickness. An increase in cardiomyocyte size accounts for left ventricular hypertrophy (LVH) during ageing [5]. It is also worth noting that while ventricular walls thicken as a result of increased cardiomyocyte size, there is actually a decrease in cardiomyocyte cell number, probably due to apoptosis [44]. Since the heart comprises cells that have little regeneration capacity, regardless of the scale of cardiomyocyte loss, the contractile efficiency would be affected [45].

An additional trigger for ageing LVH is the dilation of the aortic roots as it increases the inertial load in which the heart must pump $[44,46]$. Structural change in combination with myocardial thickening, dilation of aortic roots also results in a change in overall heart structure. The aorta dilates rightward, extending into the cavity of the left ventricle, causing a shift from elliptical to a rounded geometry and thus subjecting it to a higher wall stress [44, 47]. Overall contractile efficiency will be affected by these structural changes and the widely-used treatment thus far is with anti-hypertensive drugs such as angiotensin receptor blockers (ARBs), $\beta$-adrenoceptor antagonists, $\alpha$-adrenoceptor antagonists, calcium antagonists, angiotensin converting enzyme (ACE) inhibitors and diuretics $[48,49]$.

Table 1 Summary table listing the clinical studies with tocotrienols in cardiovascular diseases during the period of 1991-2011

\begin{tabular}{|c|c|c|}
\hline S/ & Journal title & References \\
\hline 1 & $\begin{array}{l}\text { Lowering of serum cholesterol in hypercholesterolemic humans by tocotrienols } \\
\text { (palmvitee) }\end{array}$ & $\begin{array}{l}\text { Qureshi A.A. et al. (1991). American Journal of Clinical } \\
\text { Nutrition. [79] }\end{array}$ \\
\hline 2 & $\begin{array}{l}\text { Effect of a palm-oil-vitamin E concentrate on the serum and lipoprotein lipids } \\
\text { in humans }\end{array}$ & $\begin{array}{l}\text { Tan D.T.S. et al. (1991). American Journal of Clinical Nutrition. } \\
{[17]}\end{array}$ \\
\hline 3 & $\begin{array}{l}\text { Differential serum responses of tocopherols and tocotrienols during vitamin } \\
\text { supplementation in hypercholesterolaemic individuals without change in } \\
\text { coronary risk factors }\end{array}$ & Wahlqvist M.L. et al. (1992). Nutr Res. [84] \\
\hline 4 & $\begin{array}{l}\text { Antioxidant effects of tocotrienols in patients with hyperlipidemia and carotid } \\
\text { stenosis }\end{array}$ & Tomeo A.C. et al. (1995). Lipids. \\
\hline 5 & $\begin{array}{l}\text { Novel tocotrienols of rice bran modulate cardiovascular disease risk parameters } \\
\text { of hypercholesterolemic humans. }\end{array}$ & $\begin{array}{l}\text { Qureshi A.A. et al. (1997). The Journal of Nutritional } \\
\text { Biochemistry. }\end{array}$ \\
\hline 6 & $\begin{array}{l}\text { Synergistic effect of tocotrienol-rich fraction (TRF25) of rice bran and lovastatin } \\
\text { on lipid parameters in hypercholesterolemic humans }\end{array}$ & $\begin{array}{l}\text { Qureshi A.A. et al. (2001). Journal of Nutritional Biochemistry } \\
\text { [79] }\end{array}$ \\
\hline 7 & $\begin{array}{l}\text { Dose-dependent suppression of serum cholesterol by tocotrienol-rich fraction } \\
\text { (TRF25) of rice bran in hypercholesterolemic humans }\end{array}$ & Qureshi A.A. et al. (2002). Atherosclerosis. \\
\hline 8 & $\begin{array}{l}\text { Dose Dependent Elevation of Plasma Tocotrienol Levels and Its Effect on Aterial } \\
\text { Compliance, Plasma Total Antioxidant Status, and Lipid Profile in Healthy Humans } \\
\text { Supplemented with Tocotrienols Rich Vitamin E }\end{array}$ & $\begin{array}{l}\text { Rasool A.H.G. et al. (2006) Journal of Nutritional Science and } \\
\text { Vitaminology. }\end{array}$ \\
\hline 9 & $\begin{array}{l}\text { Gamma Delta Tocotrienols Reduce Hepatic Triglyceride Synthesis and VLDL } \\
\text { Secretion }\end{array}$ & $\begin{array}{l}\text { Zaiden N. et al. (2010). Journal of Atherosclerosis and } \\
\text { Thrombosis. }\end{array}$ \\
\hline 10 & Effect of Mixed-Tocotrienols in Hypercholesterolemic Subjects & $\begin{array}{l}\text { Yuen K.H. et al. (2011). Functional Foods in Health and Disease. } \\
\text { [96] }\end{array}$ \\
\hline
\end{tabular}


Antioxidant therapy has been proposed as a promising intervention that may prevent heart failure [50]. Vitamin $\mathrm{C}$ and $\mathrm{E}$ have both been studied, either individually or in combination, in improving arterial compliance and arterial stiffness [51], which are intricately linked to ventricular hypertrophy [52]. Rasool et al., found that administration of 100 and $200 \mathrm{mg} /$ day of tocotrienols improved arterial compliance (as assessed by carotid femoral pulse wave velocity (PWV) and augmentation index (AI)) in healthy men [53]. Rasool et al. also used tocopherols in treating arterial stiffness in postmenopausal women but found that tocopherols did not show a significant improvement [54]. More studies will be needed with tocotrienols in arterial stiffness and compliance, particularly studies that compare the effects of tocotrienols and tocopherols directly, but these early data indicate that tocotrienols may be a better candidate than tocopherols in improving arterial compliance and stiffness.

As arterial compliance and stiffness are major complications reported in elderly cardiovascular patients, tocotrienols may present a suitable intervention strategy to achieve better clinical outcomes.

\section{B) Functional changes- inflammaging and immunocardiology}

The phenomenon, where low grade inflammation in the absence of other significant medical conditions, as a chronic process that eventually presents a risk factor in the elderly over time has been coined as 'inflammaging' by Claudio Franceschi [4]. There are several postulated mechanisms of inflammaging that could lead to increased susceptibility to CVD. First, an increase in senescent cells due to ageing could alter the secretion profile leading to more proinflammatory cytokines. This phenomenon is not just restricted to the cardiovascular system, but is a global process that affects the whole body.

The PolSenior study conducted in 4979 Eastern Europeans aged $\geq 65$ years, revealed that Interleukin-6 (IL-6) and C-reactive protein (CRP) levels were increased in an age-dependent manner in general. However, patients who did not have a history of CVD, type 2 diabetes, cancer or stroke exhibited a small but significantly lower level of these two markers (IL-6 and CRP) [55]. CRP levels in particular, appear to be critically linked to the development of cardiovascular diseases [56]. CRP in turn is known to be regulated by IL- 6 and tumour necrosis alpha (TNF- $\alpha$ ) [57]. A six-year study by a team at Johns Hopkins University revealed that large and sustained elevation of CRP levels are associated with a very high risk of CVD and mortality [58].

Tocotrienols have been well established as molecules that can effectively lower blood serum levels of CRP. In fact the CRP lowering activity of tocotrienols have been noted to be higher than that of tocopherol, by at least 20-50\% more [59]. This positions tocotrienols as a compound that can combat ageing related CVD via the lowering of CRP levels.

More recently, the myocardium has been scrutinised further from an immunological point of view [60-63]. These new findings have cast a spotlight on the new and emerging field of immunocardiology. New and emerging data indicate that the myocardial and immunological ageing process are intimately linked and intertwined. A study published at the time of writing, by Ramos et al., presented interesting findings in this field. The team utilised targeted cell ablations and cell-transfer methods to demonstrate that $\mathrm{CD} 4^{+} \mathrm{T}$ cells from the heart-draining lymph node of aged mice mediates low levels of cardiac inflammation and mild functional impairment even in wild type mice, in the absence of clear tissue damage or infection [64]. It is unclear from this study, however, what pathways are specifically triggered and which factors are responsible for the detrimental effects seen. This continual presence of $\mathrm{T}$ cells within the myocardium presents a further consideration as a disease-modifying factor where cardiovascular disease is concerned, certainly in the elderly.

Tocotrienols can play a role in immunomodulation of T-cell activity by regulating gene expression. Wilankar et al., reported that genes such as concanavalin A and NF$\kappa B$ were increased on short term exposure $(4 \mathrm{~h})$ but suppressed in murine lymphocytes upon long term treatment with $\gamma$-tocotrienol [65]. These two genes are associated with lymphocyte proliferation and immune activation respectively. This immunomodulation impact may potentially confer benefits in the myocardium by suppressing potentially pathogenic inflammatory activity from these immunologic cells.

\section{C) Indirect changes}

The previous two sections dealt largely with the heart itself. However, this section and the following one will deal more broadly with the cardiovascular system.

\section{i) Dyslipidemia}

Tocotrienols can alleviate hyperlipidemia and hypercholesterolemia, huge risk factors in cardiovascular disease (CVD) risks, through triglyceride (TG) and low density lipoprotein-cholesterol (LDL-C) reduction by up to $25 \%$ [66]. Work from our group previously showed the cardiovascular and metabolic health benefits of tocotrienol supplementation in tissue culture systems, rodent models as well as human studies [36, 38]. In these studies, tocotrienols reduced the production and transport of TGs in cells, rodents and human thereby reducing TG levels by $28 \%$. Tocotrienols not only lower LDL-C and 
TG, but they are also anti-inflammatory and provide multiple points of health benefits to lower CVD risk. There has been speculation that TG synthesis is lowered by modulating lipogenic gene expression based on cellular studies [67]. However more in vivo and human studies are needed to confirm this observation.

The mechanism for cholesterol reduction, however, has been elucidated to a large degree. Tocotrienols can suppress the production of 3-hydroxy-3-methyl-glutarylcoenzymeA (HMG-CoA reductase), the rate-limiting enzyme essential for cholesterol production [68]. Currently, statins remain the gold standard for the treatment of hypercholesterolemia. The mechanistic details of statin's cholesterol lowering have been worked out in great details over the years [69].

Statins mimic the structure of HMG-CoA and poses as a competitive inhibitor, for the HMG-CoA reductase [70]. While statins are considered the gold standard for treating hypercholesterolemia, it isn't without side effects. The incidence of these side effects is low however, but can nevertheless be devastating. The most common complaint is of muscle pain and soreness. In more rare and extreme cases, patients suffer rhabdomyolysis, a lifethreatening damage to the muscles [71].

While, efficacious and effective, statins, at higher doses come with unfavourable side effects such as abnormal liver function tests, nerve dysfunction and muscle disease. Statins have been increasingly shown to pose greater risk to the elderly. A longitudinal study done in elderly women in Australia revealed that these women were at greater risk of diabetes when given high doses of statin [72]. Similarly, in South Korea, a population-cased cohort study done there also revealed that a small but significant risk exists of developing new onset diabetes mellitus (NODM) with extended use of statins in the elderly [73]. Thus, while one ailment is treated, the risk for another disease goes higher.

Tocotrienols however poses no risk in developing diabetes mellitus, in fact quite the opposite effect is seen. Due to its strong antioxidant activity, studies done by Ling et al., revealed that tocotrienols can alleviate oxidative stress in the beta-cells of the pancreas [74], thus improving insulin secretion. Excessive oxidative stress is one mechanism that impairs pancreatic beta-cell health, which in turn impairs glucose-stimulated insulin secretion (GSIS). Additionally, tocotrienols have also been shown to activate the expression of peroxisome proliferator activated receptor $\gamma$ (PPAR $\gamma$ ), a key gene crucial for improving insulin sensitivity [75]. Hence, tocotrienols can also ameliorate diabetes, a metabolic condition, whilst improving cardiovascular associated morbidities.

Statins inhibit cholesterol biosynthesis by acting as a competitive inhibitor of HMG-coA, the native substrate of the enzyme HMG-CoA reductase. Tocotrienols on the other hand inhibits cholesterol biosynthesis by two different and distinct mechanisms (Fig. 2):

1) Tocotrienols catalyse the dephosphorylation of farnesyl diphosphate to form farnesol due to its farnesyl tail (in comparison tocopherols have a phytyl tail that cannot perform this step) [76]. The resultant farnesol accelerates the degradation of HMG-CoA reductase [76], thus depriving the cholesterol biosynthesis pathway of the key rate-limiting enzyme.

2) Tocotrienols inhibits HMG-CoA reductase directly, posttranscriptionally, by blocking the translation of the mRNA $[76,77]$.

A number of human trials have been conducted to investigate tocotrienols potential in lowering dyslipdemia, including hypercholesterolemia [66, 78-82], and all these studies have demonstrated significant improvement ameliorating the clinical parameters of dyslipidemia tested. There have been also studies that did not observe significant differences in improving dyslipidemia [8385], including LDL-C and cholesterol parameters. We however note that in these studies, the subjects were not given a standardised diet or this information was not clear from the study, which could have led to confounding analysis of the resultant data. The inclusion criteria for some of these studies were also too broad, perhaps being another confounding factor. For example, Wahlqvist et al., employed a wide age range (25-75) [84], whereas it is well established that the basal metabolic rate of different age groups can affect the study outcome $[86,87]$.

There has been some interest in understanding the combinatorial effect of statin and tocotrienol. A study reported by Qureshi et al. demonstrated that cotreatment with lovastatin and tocotrienols led to a synergistic effect in improving the lipid profile of hypercholesterolemic subjects [88]. In other studies, combined treatment with tocotrienols and lovastatin have led to a decrease in cell proliferation in human cancer cell lines $[89,90]$. Nevertheless, with the concerns posed by the intake of statins in the elderly, as discussed, there has been some caution with this approach.

Intriguingly, tocopherols, the more widely available form of Vitamin E, is known to antagonise the ability of tocotrienols to suppress HMG-CoA reductase. When tocopherol is added together with tocotrienols, cholesterol reduction is attenuated in cell culture [91], and animals [92, 93]. This antagonistic effect has not yet been unequivocally demonstrated in humans, possibly due to the complexities of interpreting data from the effects of more than one compound. 


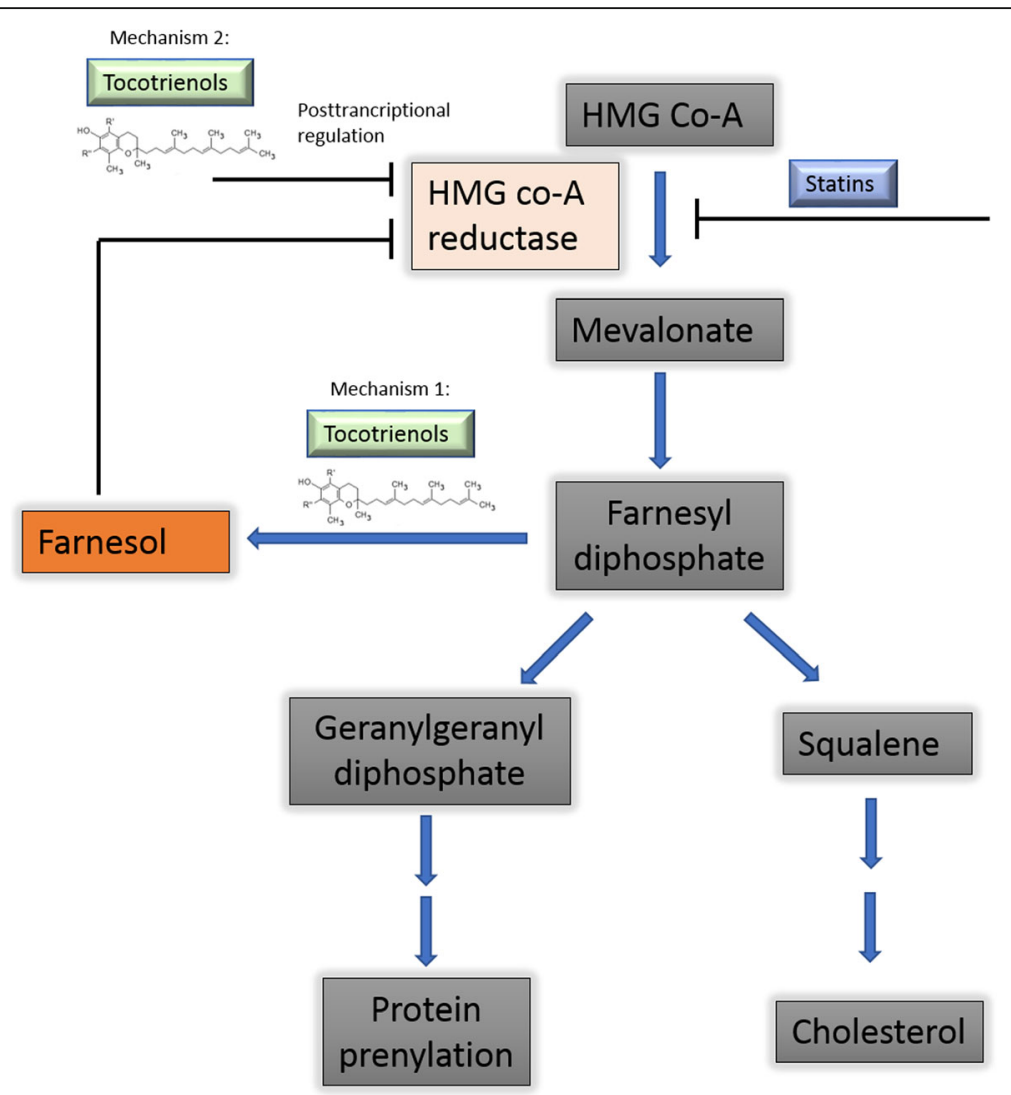

Fig. 2 Tocotrienols lower cholesterol via 2 distinct mechanisms that ultimately operate on reducing the function of HMG-CoA reductase in catalysing the rate limiting step in cholesterol biosynthesis, as opposed to statins that have one mechanism of action, competitive inhibition by mimicking the native substrate HMG Co-A and binding the active site of HMG-CoA reductase. Mechanism 1 involves increasing the conversion of farnesyl diphosphate to farnesol, and this intermediate in turn accelerates the degradation of HMG Co-A reductase. Mechanism 2 involves a posttranscriptional means of regulation, by inhibiting the translation of HMG Co-A reductase MRNA. Both these mechanisms converge on HMG co-A reductase, the key rate-limiting enzymatic step in cholesterol biosynthesis

However, most human studies employing $\alpha$-tocopherol show no effect in reducing cholesterol or improving clinical dyslipidemia [94-96].

\section{li) lipid peroxidation and adhesion}

Atherosclerosis is now well recognised as a chronic inflammatory disease. This disease is characterised by the accumulation of various species of lipids and inflammatory cells (which eventually form foam cells) in the arterial walls [97]. Endothelial injury and dysfunction are fundamental stimuli responsible for the formation of atherosclerotic plaque, and vascular wall inflammation is the key factor in the aetiology of atherosclerosis [98].

Oxidised LDL (ox-LDL) is a critical factor in the pathophysiology of atheromatous plaque, and this occurs due to lipid peroxidation by reactive oxygen species (ROS) (discussed more in Section D). Ox-LDL is preferentially taken up by macrophages via the scavenger receptors on these cells. This is done via non-LDL receptor pathway and as such it is unregulated and has no saturation point, allowing as much of these radicalised particles to enter the macrophages. Ultimately the macrophages convert to foam cells, which is a key turning point in the pathogenesis of atherosclerosis [25, 97-99]. Atherosclerosis-related clinical complications include coronary artery disease (CAD), stroke and other peripheral vascular diseases. CAD is one of the biggest killers in most developed and developing nations today [100].

Dietary tocotrienols have been shown to have a preventive role in the development of atherosclerosis in both animal models and humans [17]. $\alpha$-tocotrienol, for an instance, has been shown to be 40 times more effective than $\alpha$-tocopherol in providing protection to rat liver microsomal membranes from oxidative stress and damage [101]. $\alpha$-tocotrienol was also found to show higher peroxyl radical scavenging potential than $\alpha$-tocopherol in liposomal membranes [24]. More recently, however, $\delta$-tocotrienol is becoming regarded as the homologue with strongest activity amongst tocotrienols where lipid peroxidation inhibition is concerned [102]. 
In humans, tocotrienols are reported to lower the stimulated endothelial cell expression of adhesion molecules (sVCAM-1, sICAM-1 AND e-selectin) by preventing the activation of NF-kB. By so doing, monocyteendothelial cell adhesion is also decreased, and this correlation was seen to operate in a dose-dependent manner [103]. These findings have been also reproduced and expanded upon by other researchers [104, 105]. Similar to what was seen in the rodent studies earlier, $\delta$ tocotrienol shown to be the most robust inhibitory effect on inhibiting the expression of sVCAM-1 in both these studies.

In recent times, and as alluded to when discussing dyslipidemia earlier, tocotrienols have been shown to be important in activating PPAR family of nuclear receptors, namely PPAR $\alpha$, PPAR $\gamma$ and PPAR $\delta$ [75]. A diet rich in palm-derived TRF was found to reduce atherosclerosis development in $\mathrm{ApoE}^{-/-}$mice through peroxisome proliferator activated receptor (PPAR) target gene liver $\mathrm{X}$ receptor alpha $(\mathrm{LXR} \alpha)$ as well as other downstream target genes such as apolipoproteins and cholesterol transporters [106]. This suggests that another important aspect of tocotrienol activity in preventing atherosclerosis is by modulating PPAR activity. The mechanistic details as to how this is achieved is still a subject of intense research as at the time of writing.

In summary, tocotrienols may confer antiatherosclerotic in a multi-pronged fashion, by not just being antioxidative and anti-inflammatory, but also in modulating the expression of important proteins are vital in the development of atherosclerosis, particularly in the elderly.

\section{lii) hypertension}

Arterial hypertension, or more commonly referred to as high 'blood pressure' (BP), is defined as systolic BP of greater than $140 \mathrm{mmHG}$ or diastolic $\mathrm{BP}$ greater than 90 mmHG [107]. Ageing is linked to functional, structural and mechanical changes in arteries that closely resemble the vascular changes observed in the pathogenesis of hypertension [108]. There is now almost irrefutable evidence from a huge number of clinical trials that lowering hypertension can reduce the incidence of myocardial infarction [109].

A number of treatments exist in lowering systolic or diastolic BP. Most well-known of these are perhaps the 'beta-blockers', so-called because they block the betaadrenergic receptors, thus leading to endothelium relaxation and lowering of BP [110]. Over the years, betablockers have proven to be efficacious in several other indications as well, most notably anxiety [111]. However, there have been a number of adverse events reported with the use of beta-blockers. Studies done with the elderly, in particular, report increased number of adverse events [112], and also more limited efficacy in addressing hypertension and cardiovascular-associated morbidities [113].

In addressing the above concerns, alternative and more recent medications have been used for the elderly. These include angiotensin receptor blockers (ARB), angiotensin converting enzyme (ACE) inhibitors and calcium channel blockers (CCB's) [112, 114, 115]. Comparative studies done with ARB's, ACE inhibitors and CCBs versus beta-blockers indeed show greater efficacy and reduced adverse events. [116-118] . For example, Kuti et al., reported reduced odds of developing new onset type 2 diabetes with CCBs compared to betablockers [119]. However, side effects such as dizziness and edema are also reported with some of these new medications [120].

Several studies in recent times have also reported the benefits of dietary antioxidants in reducing BP. Notable of these, is the 'Dietary Approaches to Stop Hypertension (DASH) study [121], which is a multicentre, randomized, controlled-feeding trial where various combination of food items in lowering BP were studied. Diets rich in antioxidant Vitamin C (266 mg/day compared to $133 \mathrm{mg} /$ day in the control group) was found to lower BP by 5.5/3.0 $\mathrm{mmHG}$ (systole/diastolic) in a subpopulation with moderately high BP and 11.5/3.0 mmHG in a subpopulation with clinical hypertension. The DASH study however doesn't investigate the effect of a single nutrient, thus not allowing us to narrow down to the exact causative factor(s) of the observed improvement in hypertension. Since the DASH study however, more studies focussing on individual antioxidant nutrients have been conducted which includes tocotrienols [107].

Studies involving the role of tocotrienols in hypertension are currently limited to animal models, but the resulting data appear promising. Muharis et al., reported that palm-derived TRF may potentially improve vascular endothelial function in hypertension by improving endothelium relaxation in rat aortae [122]. Another study by Ali and Woodman, also done using palm-derived TRF, reported that TRF is better than pure tocotrienols at improving endothelium-dependent relaxation in rat aortae, suggesting that the combined effect of tocotrienols and $\alpha$-tocopherol are both important in bringing about the improvement seen in the endothelium [23]. A follow-up study by the same team, using a similar setup as previously, but this time incorporating a high-fat diet, reported a similar improvement in endotheliumdependent relaxation, when given TRF [123]. Thus, palm-derived TRF, could provide a unique therapeutic opportunity for the elderly, by preventing the potential adverse effects seen with stronger pharmacological agents as described earlier. Ultimately, human studies 
will need to be conducted to confirm these beneficial effects in improving hypertension. However, these preclinical data do provide a strong basis to conduct further investigation in humans.

\section{D) Decreased capacity to handle oxidative stress - Mitochondrial dysfunction}

Reactive oxygen species (ROS) and reactive nitrogen species (RNS) have been firmly established as both potentially harmful, but also potentially beneficial as signalling molecules in certain instances [124-127]. Both ROS and RNS are normally generated by tightly regulated enzymes such as nitric oxide synthase (NOS) and nicotinamide adenine dinucleotide phosphate (NADPH) oxidase. The mitochondrial electron transport chain is another source for the generation of ROS/RNS. The chronic overproduction of ROS/RNS, a phenomenon often linked with ageing [128], can be damaging to various parts of cell and tissue components, especially since it directly damages the important biomolecules key to sustaining life, such as lipid (lipid peroxidation), proteins and even DNA [126, 128, 129].

Harman proposed the free radical theory of ageing in the 1950s and this was later expanded in the 1970s to reflect the role of the mitochondria in the generation of ROS/RNS [128]. In a nutshell, this theory states that the ageing process is known to accelerate the overproduction of these species, leading to an increased oxidative burden that needs to be cleared by the body. The longer these ROS/RNS species occupy the system without being cleared, the higher the likelihood of them causing harm to the body. In the heart, the decline in function in the mitochondrial respiratory chain complexes, particularly complexes I and IV have been identified as one of the major reason for this [130].

This deterioration in mitochondrial energetics and function, leading to mitochondrial dysfunction, is gaining recognition as a major determinant in ageing-related cardiovascular disease [131]. A similar type of mitochondrial dysfunction is seen in radiation-induced heart disease (RIHD). In RIHD, exposure to radiation (such as in radiotherapy) leads to an increase in membrane permeability and subsequently impaired functionality of the respiratory chain complexes. One study by Sridharan et al., demonstrated the efficacy of TRF in ameliorating mitochondrial dysfunction by sustaining succinatedriven mitochondrial respiration. It is likely that these benefits could be conferred to the elderly afflicted with cardiac disease, particularly if the pathological state can be linked to mitochondrial dysfunction.

\section{i) Myocardial ischemia \& heart failure}

Ischemic heart disease (IHD) is a common form of cardiovascular disease that ultimately results in myocardial infarction. Myocardial ischemia results from a disruption in the coronary blood supply, and the majority of this is attributed to atherosclerosis. But, apart from atherosclerosis, oxidative stress in itself plays an important role in the pathogenesis of IHD $[130,132]$.

In post-ischemic myocardium, increased levels of ROS are also generated in the cardiomyocytes, endothelial cells, and infiltrating neutrophils. These in turn carve the path towards cellular dysfunction and necrosis. Substantial evidence exists to support the role of oxidative stress as one of the major aetiologies for myocardial injury $[97,127,128,131]$. Besides, oxidative stress it thought to cause the occurrence of cardiac events after reperfusion therapy in acute coronary syndrome (ACS) [133]. Feng et al. demonstrated the correlation between increased oxidative stress marker plasma advanced oxidation protein products (AOPP) concentration and increased incidence of major cardiac events in patients treated with percutaneous coronary intervention for STsegment elevation myocardial infarction during a sixmonth follow up [134]. In addition, Hokamaki et al. also showed that patients with high thioredoxin levels suffered from a more frequent recurrent angina attack as compared to patients with low thioredoxin levels after treatment of unstable angina [135]. Apart from that, studies have also revealed that there is a correlation among oxidative stress, ventricular remodelling and progressive dilatation leading to end-stage heart failure. Indeed, increased levels of oxidative stress biomarker such as malondialdehyde, lipid peroxidases, glutathione peroxidase, thioredoxin or superoxide dismutase have been shown to be associated with heart failure both acute and chronic conditions [136-138]. Additionally, these conditions are made worse by nitrate therapy, used widely in the treatment of both coronary artery disease and congestive heart failure. Apart from rapid development of nitrate tolerance, Munzel et al., reported that in vivo nitrate use can lead to the generation of superoxide anions from the endothelium [139]. Fan et al., conducted a clinical trial to investigate the effects of nitrate therapy and confirmed the significant increase of ROS/RNS in the elderly compared to younger patients [128].

The superior free radical scavenging activity demonstrated by tocotrienols, should lead to a considerable attenuation in oxidative stress-induced IHD as well as post-ischemic myocardial therapy. Studies conducted by a couple of groups have postulated that the cardioprotective value from tocotrienols may stem from their ability to stabilise proteasomes $[140,141]$. Proteasomes become destabilised after ischemia [141, 142]. The ability to stabilise proteasomes after an ischemic episode allows a better balance between survival and apoptotic signals, improving myocardial health. 


\section{li) atrial fibrillation}

Atrial fibrillation (AF) is the most frequent postoperative complication after cardiac surgery afflicting the elderly. The prevalence rate of AF can range from $25 \%$ for coronary artery bypass surgery to $65 \%$ for in-valve replacement procedures. Postoperative AF after cardiac surgery not only doubles the morbidity rate but can increase mortality as well. Oxidative stress has been implicated in the pathogenesis of AF [143], and naturally antioxidant therapy has been suggested as an intervention strategy.

Interestingly, both Vitamin C and Vitamin E (tocopherols), have been investigated and proposed as a suitable prophylactic agent for addressing AF in numerous studies [143-146]. In particular, a meta-analysis conducted by Hemila and Suonsyrja found that of the 15 trials that used Vitamin $\mathrm{C}$ as a prophylactic treatment, AF risk was reduced by $27 \%$ on average, although the study also did report a huge heterogeneity in the way these 15 studies were conducted [145].

A recent study investigated if serum Vitamin E (tocopherol) level was related to AF recurrence in patients undergoing electrical cardioversion (EC) [147]. One hundred and forty-four consecutive patients who underwent successful EC were prospectively enrolled and followed for 3 months. It was indicated that low serum Vitamin E level was an independent predictor for AF recurrence.

Another study by Rodrigo and colleagues even postulated, based on their data, that Vitamin $\mathrm{C}$ therapy, in combination with omega-3 polyunsaturated fatty acid (PUFA), could become more efficacious with ageing when treating AF [144]. Given what is known about the potent antioxidant activity, compared to Vitamin $\mathrm{C}$ and tocopherols, tocotrienols could potentially further reduce the risk in AF, and presents a unique and novel method for addressing postoperative AF.
To our knowledge, no study examining the effect of tocotrienols have been conducted to date. Given these interesting findings with regards to antioxidant therapy, it is likely that tocotrienols could emerge as a potential candidate for treating AF based on its antioxidative profile.

\section{Conclusion}

Whilst numerous reviews extolling the benefits of tocotrienols in cardiovascular diseases have been written, we chose to focus our review on a more specific subset of cardiovascular disease, namely ageing-related cardiovascular diseases (Fig. 3). With the advent of modern medicine and the technologies that accompany it, we have managed to prolong our lifespans and age gracefully.

Whilst prolonging our mortality has been a great achievement for mankind in medical science, we still grapple with some of the consequences of ageing, and cardiovascular-associated morbidities are one of them [148]. The ageing process is also one that is mired with increased oxidative stresses and inflammation. Pharmacological agents in the form of synthetic entities, exist to treat these ailments or its symptoms, but there can often be harsh side effects, which are often made worse in the elderly. As a result, there is an increasing interest in turning to compounds that exist naturally in nature and to harness their potential for clinical interventional strategies.

Apart from tocotrienols, two other compounds that are gaining interest in this field is curcumin and resveratrol. These two examples fall under the family of polyphenols. Significant research has demonstrated the antioxidant and anti-inflammatory effects of curcumin [149] and resveratrol [150], in the treatment of cardiovascular diseases The polyphenol, curcumin, is the active component of turmeric, a common Indian spice, derived

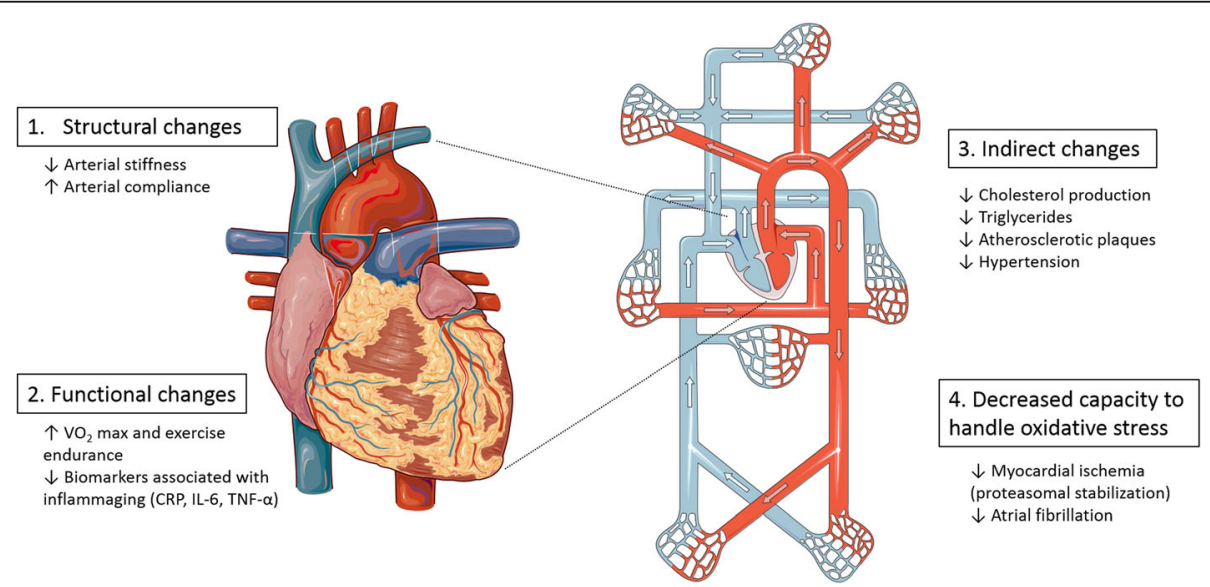

Fig. 3 Summary of the potential cardiovascular benefits conferred by tocotrienol consumption in the elderly. Images are adapted from Servier Medical Art (http://smart.servier.com/) 
from the rhizome of the Curcuma longa plant. Curcumin is the most abundant constituent of turmeric; comprising approximately $2 \%-5 \%$ of the compound [151]. Curcumin has been particularly noted in its ability to suppress inflammation by regulating multiple cytokines such as beta-site APP-cleaving enzyme (BACE-1), C-reactive protein (CRP) and MMPs, TNF $\alpha$ and NF-kB [151]. It has additionally been suggested that curcumin may modulate hypertrophy in the aging heart by inhibiting the Adenoviral transcription co-activator, p30 [149]. Interestingly, $\alpha$-tocopherol levels were found to be greater with curcumin supplementation indicating the enhancement of endogenous antioxidant mechanisms. Despite the strong evidence, curcumin suffers from a poor bioavailability as evidenced in clinical trials [152]. Resveratrol has been extensively researched for its ability to modulate determinants that are linked with increased cardiovascular risk, in particular by stimulating the activity of sirtuins, particularly SIRT1, a histone deacetylase. Resveratrol is also a COX1 inhibitor which translates to reduced endothelial inflammation [153]. Elevated levels of resveratrol mimic caloric restriction in older adults, and the cardiovascular benefits of these are well documented. However, there is also evidence to show that in certain circumstances polyphenols such as resveratrol can bind and form complexes with proteins and minerals, thus impairing its efficacy. Thus, it is worth considering other potential alternatives such as tocotrienols.

Tocotrienols have been receiving a great deal of attention over the last 3 decades, especially with the discovery of its potential to ameliorate a wide range of disease conditions, due its superior antioxidant and antiinflammatory activity.

It might perhaps be surprising as to how such a potent compound with enormous potential has not been hugely exploited yet. As mentioned earlier, apart from being a recent discovery, tocotrienols present a challenge in its pharmacokinetic and pharmacodynamic profile. From Fig. 1, one could see why this is the case. Tocotrienols present $3 \mathrm{C}-\mathrm{C}$ double bonds in their phytyl tail, as opposed to tocopherols, that have completely saturated C-C bonds. This makes tocotrienols much more hydrophobic or lipophilic, than its counterpart tocopherol, and subsequently a challenge to deliver orally. Nevertheless, there has been noteworthy progress in these areas. Self-emulsifying drug delivery systems (SEDDS), which employ a clever composition of isotropic mixtures of oils, surfactants, solvents and co-solvents/surfactants is one major strategy employed in devising formulations in order to improve the oral absorption of highly lipophilic natural compounds [154-156].
There have also been concerns about the potential side effect that tocotrienols could present in humans. It has been shown that tocotrienols exhibit lower $\mathrm{IC}_{50}$ concentration than tocopherols for the same concentration. However, up to date, there have been no serious adverse events reported in humans in all the human trials reported so far in the literature or on Clinicaltrials.gov. One study by Springett et al., performed dose-escalation studies of up to $3200 \mathrm{mg}$ of pure delta-tocotrienol [157], which is one of the highest used in the literature to our knowledge. At this level, 2 patients reported diarrhoea. However, $3.2 \mathrm{~g}$ per day is not a feasible amount to consume daily from a practical point of view.

There have also been some concerns raised in recent times, if a highly potent anti-inflammatory compound might be so potent as to suppress even the normal immune functions of the body. After all, inflammation is a natural response of the human body to combat infection and other potentially injurious agents to our system. The possible side effects of anti-inflammatory agents to the host defence in a recent review in Cell [158]. Most of what was discussed however involved pharmaceutical drug compounds. Most, if not all, of these drug compounds are synthesised in the laboratory whereas nutraceutical compounds such as tocotrienols come from nature and have co-evolved with humans and other organisms over the course of time [159, 160]. Humans have in fact been consuming tocopherols and tocotrienols (albeit as a mixture with other nutrients and at much lower levels) from food products such as barley and rice for thousands of years. Thus, the human body have had a long time to adapt to tocotrienols and it is unlikely any major compromise would occur in the host defence. While no major side effects have been described with the use of tocotrienols, as mentioned above, future trials may be warranted to consider the immune function of individuals consuming tocotrienols as an enriched fraction however. Thus, based on the evidence available to date, tocotrienols are a safe and potential candidate in improving cardiovascular health, especially for the elderly, who can be more susceptible more aggressive pharmaceutical interventions. In addition to this, there are also other health benefits related to reducing oxidative stress and pathological inflammation which plays a role in providing holistic health benefits for the elderly.

\section{Abbreviations}

ACE: Angiotensin converting enzyme; ACS: Acute coronary syndrome; AF: Atrial fibrillation; AOPP: Advanced oxidation protein products; ARB: Angiotensin receptor blocker; CCB: Calcium channel blocker; CRP: Creactive protein; CVD: Cardiovascular disease; EC: Electrical cardioversion; IHD: Ischemic heart disease GRAS: Generally Regarded as Safe; LVH: Left ventricular hypertrophy; NOS: Nitric oxide synthase; PUFA: Polyunsaturated fatty acids; RNS: Reactive nitrogen species; ROS: Reactive oxygen species; 
SEDDS: Self-emulsifying drug delivery system; TG: Triglyceride;

TRF: Tocotrienol-rich fraction; WHO: World Health Organisation

\section{Acknowledgments}

We would like to thank Nicole Min Qian Pek from the Institute of Molecular and Cellular Biology, Singapore for useful inputs in revising this article.

\section{Funding}

None

\section{Availability of data and materials}

Not applicable as no datasets were generated or analysed for this article.

\section{Authors' contributions}

NR conceived and led the writing of the manuscript with substantial writing contribution from ET, LLJ, SBS and YWN. All authors approved the final version of the manuscript.

\section{Ethics approval and consent to participate}

Not applicable

\section{Consent for publication}

Not applicable

\section{Competing interests}

NR and YWN work for Davos Life Science Pte Ltd., a company that produces phytonutrients, which includes tocotrienols and a-tocopherol, from palm oil. The rest of the authors declare that they have no competing interests.

\section{Publisher's Note}

Springer Nature remains neutral with regard to jurisdictional claims in published maps and institutional affiliations.

\section{Author details}

'Department of R\&D, Davos Life Science Pte Ltd, 3 Biopolis Drive, \#04-19, Davos 138623, Singapore. ${ }^{2}$ Department of R\&D, Level 8, Menara KLK 1,Jalan Pju 7/6,Mutiara Damansara, 47810, 47800 Petaling Jaya, Selangor, Malaysia. ${ }^{3}$ Disease Modeling and Therapeutics Laboratory, Institute of Molecular and Cell Biology, 61 Biopolis Drive Proteos, Singapore 138673, Singapore. ${ }^{4}$ Department of Biological Sciences, National University of Singapore, Singapore 117543, Singapore. ${ }^{5}$ Key Laboratory for Major Obstetric Diseases of Guangdong Province, The Third Affiliated Hospital of Guangzhou Medical University, Guangzhou 510150, China.

\section{Received: 27 July 2017 Accepted: 15 January 2018}

\section{Published online: 19 January 2018}

\section{References}

1. WHO | Cardiovascular diseases (CVDs). WHO. World Health Organization; 2016;

2. Romano AD, Serviddio $G$, de Matthaeis A, Bellanti F, Vendemiale $G$. Oxidative stress and aging. J Nephrol. 23(Suppl 15):S29-36. Available from: http://www.ncbi.nlm.nih.gov/pubmed/20872368. [cited 2017 Jun 14]

3. Franceschi C, Capri M, Monti D, Giunta S, Olivieri F, Sevini F, et al. Inflammaging and anti-inflammaging: a systemic perspective on aging and longevity emerged from studies in humans. Mech Ageing Dev. 2007;128: 92-105. Available from: http://linkinghub.elsevier.com/retrieve/pii/ S0047637406002491. [cited 2017 May 29]

4. Franceschi C, Campisi J. Chronic Inflammation (Inflammaging) and Its Potential Contribution to Age-Associated Diseases. J Gerontol Ser A Biol Sci Med Sci. 2014;69:S4-9. [cited 2017 May 18] Available from: https://academic. oup.com/biomedgerontology/article-lookup/doi/10.1093/gerona/glu057. Oxford University Press

5. Strait JB, Lakatta EG. Aging-Associated Cardiovascular Changes and Their Relationship to Heart Failure. Heart Fail Clin. 2012;8:143-64. [cited 2016 Dec 5] Available from: http://www.ncbi.nlm.nih.gov/pubmed/22108734.

6. von Moltke LL, Greenblatt DJ, Romach MK, Sellers EM. Cognitive toxicity of drugs used in the elderly. Dialogues Clin Neurosci. 2001;3:181-90. [cited 2017 Apr 21] Available from: http://www.ncbi.nlm.nih.gov/pubmed/ 22034128.

7. Berger NA, Savvides P, Koroukian SM, Kahana EF, Deimling GT, Rose JH, et al. Cancer in the elderly. Trans. Am. Clin. Climatol. Assoc.; 2006 [cited 2017
Apr 21];117:147-55-6. Available from: http://www.ncbi.nlm.nih.gov/pubmed/ 18528470

8. Sipahimalani A, Masand PS. Use of risperidone in delirium: case reports. Ann Clin Psychiatry. The Fellowship of Postgraduate Medicine; 1997 [cited 2017 Apr 21];9:105-107. Available from: http://www.ncbi.nlm.nih.gov/pubmed/ 9242897.

9. Bent S. Herbal medicine in the United States: review of efficacy, safety, and regulation: grand rounds at University of California, San Francisco Medical Center. J Gen Intern Med. 2008;23:854-9. cited 2017 Apr 21]; Available from: http://www.ncbi.n/m.nih.gov/pubmed/18415652.

10. Wachtel-Galor S, IFF B. Herbal Medicine: An Introduction to Its History, Usage, Regulation, Current Trends, and Research Needs. Herb Med Biomol Clin Asp. 2011; CRC Press/Taylor \& Francis [Cited 2017 Apr 21]. Available from: http://www.ncbi.nlm.nih.gov/pubmed/22593939.

11. Frenkel M, Ben-Arye $E$, Hermoni D, Bernard T, Bhola S, Fortuné M, et al. An approach to educating family practice residents and family physicians about complementary and alternative medicine. Complement Ther Med. 2004;12: 118-25. [cited 2017 Apr 21] BioMed CentralAvailable from: http://linkinghub. elsevier.com/retrieve/pii/S0965229904000822.

12. Calixto JB. Efficacy, safety, quality control, marketing and regulatory guidelines for herbal medicines (phytotherapeutic agents) Brazilian. J Med Biol Res. 2000;33:179-89. [cited 2017 Apr 21] Available from: http://www. scielo.br/scielo.php?script=sci_arttext\&pid=S0100-879X2000000200004

13. Mustapha N, Singh H, Basdeo L, Blades A, Francis M-J, Gomes N, et al. Health care for the disadvantaged. Public Health. 1999:113:307-9. [cited 2017 Apr 21] BioMed Central. Available from: http://linkinghub.elsevier.com/ retrieve/pii/S0033350699001869

14. Zhang AL, Changli Xue C, HHS F. Integration of Herbal Medicine into Evidence-Based Clinical Practice: Current Status and Issues. Herb Med Biomol Clin Asp. 2011; CRC Press/Taylor \& Francis [Cited 2017 Apr 21]. Available from: http://www.ncbi.nlm.nih.gov/pubmed/22593929.

15. Halliwell B. Oxidative stress, nutrition and health. Experimental strategies for optimization of nutritional antioxidant intake in humans. Free Radic Res. 1996;25:57-74. [cited 2017 Apr 18] Available from: http://www.ncbi.nlm.nih. gov/pubmed/8814444

16. Fang $Y-Z$, Yang $S$, Wu G. Free radicals, antioxidants, and nutrition. Nutrition. 2002;18:872-9. [cited 2017 Apr 18] Available from: http://www.ncbi.nIm.nih. gov/pubmed/12361782.

17. Tan B, Watson RR, Preedy VR. Tocotrienols: Vitamin E Beyond Tocopherols. 2nd ed; 2013. CRC Press; [cited 2015 Sep 15]. Available from: https://books. google.com/books?hl=en\&lr=\&id=RhDSBQAAQBAJ\&pgis=1.

18. Evans HM, Bishop KS. ON THE EXISTENCE OF A HITHERTO UNRECOGNIZED DIETARY FACTOR ESSENTIAL FOR REPRODUCTION. Science. 1922:80:56.

19. Grilo EC, Costa PN, CSS G, AF de L B, FN de S A, Dimenstein R. Alphatocopherol and gamma-tocopherol concentration in vegetable oils. Food Sci Technol. 2014;34:379-85. SBCTA [cited 2017 Jun 12] Available from: http://www.scielo.br/scielo.php?script=sci_arttext\&pid=S010120612014000200024\&lng=en\&nrm=iso\&tlng=en

20. Qureshi AA, Burger WC, Peterson DM, Elson CE. The structure of an inhibito of cholesterol biosynthesis isolated from barley. J Biol Chem. 1986;261: 10544-50. [cited 2017 Jan 5] Available from: http://www.ncbi.nlm.nih.gov/ pubmed/3733719.

21. Sen CK, Khanna S, Roy S. Tocotrienols: Vitamin E beyond tocopherols. Life Sci. 2006;78:2088-98. [cited 2015 Feb 24] Available from: http://www. pubmedcentral.nih.gov/articlerender.fcgi?artid=1790869\&tool= pmcentrez\&rendertype=abstract

22. Qureshi AA, Khan DA, Saleem S, Silswal N, Trias AM, Tan B, et al. Pharmacokinetics and Bioavailability of Annatto $\delta$-tocotrienol in Healthy Fed Subjects. 2015:6.

23. Ali SF, Woodman OL. Tocotrienol Rich Palm Oil Extract Is More Effective Than Pure Tocotrienols at Improving Endothelium-Dependent Relaxation in the Presence of Oxidative Stress. Oxidative Med Cell Longev. 2015, 2015: 150829. [cited 2015 Jul 24] Available from: http://www.pubmedcentral.nih. gov/articlerender.fcgi?artid=4449936\&tool=pmcentrez\&rendertype=abstract

24. Suzuki YJ, Tsuchiya M, Wassall SR, Choo YM, Govil G, Kagan VE, et al. Structural and dynamic membrane properties of alpha-tocopherol and alpha-tocotrienol: implication to the molecular mechanism of their antioxidant potency. Biochemistry. 1993:32:10692-9. [cited 2016 Nov 28] Available from: http://www.ncbi.nlm.nih.gov/pubmed/8399214.

25. Serbinova E, Kagan V, Han D, Packer L. Free radical recycling and intramembrane mobility in the antioxidant properties of alpha-tocopherol 
and alpha-tocotrienol. Free Radic Biol Med. 1991;10:263-75. [cited 2016 Nov 28] Available from: http://www.ncbi.nlm.nih.gov/pubmed/1649783

26. Singh U, Jialal I. Anti-inflammatory Effects of a-Tocopherol. Ann N Y Acad Sci. 2004;1031:195-203. [cited 2017 Jan 24] Available from: http://www.ncbi. nlm.nih.gov/pubmed/15753145

27. Reiter $E_{\text {, Jiang }} \mathrm{Q}$, Christen $\mathrm{S}$. Anti-inflammatory properties of $\mathrm{a}$ - and $\mathrm{y}$ tocopherol. Mol Asp Med. 2007;28:668-91. [cited 2017 Jan 24] Available from: http://www.ncbi.nlm.nih.gov/pubmed/17316780.

28. Wong W-Y, Ward LC, Fong CW, Yap WN, Brown L. Anti-inflammatory $Y$ - and $\delta$-tocotrienols improve cardiovascular, liver and metabolic function in dietinduced obese rats. Eur J Nutr. 2015; Springer Berlin Heidelberg Available from: http://link.springer.com/10.1007/s00394-015-1064-1.

29. Kwang SA, Sethi G, Krishnan K, Aggarwal BB. $y$-tocotrienol inhibits nuclear factor-KB signaling pathway through inhibition of receptor-interacting protein and TAK1 leading to suppression of antiapoptotic gene products and potentiation of apoptosis. J Biol Chem. 2007;282:809-20.

30. Nesaretnam K, Meganathan P. Tocotrienols: inflammation and cancer. Ann N Y Acad Sci. 2011;1229:18-22.

31. Ndlovu MN, Van Lint C, Van Wesemael K, Callebert P, Chalbos D, Haegeman G, et al. Hyperactivated NF- B and AP-1 Transcription Factors Promote Highly Accessible Chromatin and Constitutive Transcription across the Interleukin-6 Gene Promoter in Metastatic Breast Cancer. Cells Mol Cell Biol. 2009;29:5488-504. Available from: http://mcb.asm.org/cgi/doi/10.1128/MCB. 01657-08.

32. Khanna S, Roy S, Parinandi NL, Maurer M, Sen CK. Characterization of the potent neuroprotective properties of the natural vitamin E alphatocotrienol. J Neurochem. 2006;98:1474-86. [cited 2016 Nov 17] Available from: http://www.ncbi.nlm.nih.gov/pubmed/16923160.

33. Park HA, Kubicki N, Gnyawali S, Chan YC, Roy S, Khanna S, et al. Natural vitamin e a-tocotrienol protects against ischemic stroke by induction of multidrug resistance-associated protein 1. Stroke. 2011;42:2308-14.

34. Khanna S, Roy S, Slivka A, Craft TKS, Chaki S, Rink C, et al. Neuroprotective properties of the natural vitamin E alpha-tocotrienol. Stroke. 2005;36:225864. [cited 2015 Aug 31] Available from: http://www.pubmedcentral.nih.gov/ articlerender.fcgi?artid=1829173\&tool=pmcentrez\&rendertype=abstract.

35. Khanna S, Parinandi NL, Kotha SR, Roy S, Rink C, Bibus D, et al. Nanomolar vitamin $\mathrm{E}$ alpha-tocotrienol inhibits glutamate-induced activation of phospholipase A2 and causes neuroprotection. J Neurochem. 2010;112: 1249-60. NIH Public Access; [cited 2016 Dec 21] Available from: http://www. ncbi.nlm.nih.gov/pubmed/20028458.

36. Wong W-Y, Ward LC, Fong CW, Yap WN, Brown L. Anti-inflammatory $Y$ - and $\delta$-tocotrienols improve cardiovascular, liver and metabolic function in dietinduced obese rats. Eur J Nutr. Springer Berlin Heidelberg; 2015 [cited 2016 Feb 2]; Available from: http://www.ncbi.nlm.nih.gov/pubmed/26446095.

37. Wong $W-Y Y$, Poudyal $H$, Ward LC, Brown L. Tocotrienols reverse cardiovascular, metabolic and liver changes in high carbohydrate, high fat diet-fed rats. Nutrients. 2012:4:1527-41. [cited 2016 Feb 1] Available from: http://www.pubmedcentral.nih.gov/articlerender.fcgi?artid=3497010\&tool= pmcentrez\&rendertype $=$ abstract

38. Zaiden N, Yap WN, Ong S, Xu CH, Teo VH, Chang CP, et al. Gamma delta tocotrienols reduce hepatic triglyceride synthesis and VLDL secretion. J Atheroscler Thromb. 2010;17:1019-32.

39. US FDA GRAS Notice No:307. Available from: http://www.accessdata.fda. gov/scripts/fdcc/?set=GRASNotices\&id=307.

40. Chin S-F, Hamid NAA, Latiff AA, Zakaria Z, Mazlan M, Yusof YAM, et al. Reduction of DNA damage in older healthy adults by Tri E Tocotrienol supplementation. Nutrition. 2008;24:1-10. [cited 2016 Jun 22] Available from: http://www.ncbi.nlm.nih.gov/pubmed/17884341

41. Gopalan Y, Shuaib IL, Magosso E, Ansari MA, Abu Bakar MR, Wong JW, et al. Clinical investigation of the protective effects of palm vitamin e tocotrienols on brain white matter. Stroke. 2014;45:1422-8.

42. Ahsan $\mathrm{H}$, Ahad A, Iqbal J, Siddiqui WA. Pharmacological potential of tocotrienols: a review. Nutr Metab (Lond). 2014;11:52. [cited 2016 Sep 23] [Internet]. BioMed Central Available from: http://www.ncbi.nlm.nih.gov/ pubmed/25435896

43. Murray CJ, Lopez AD. Alternative projections of mortality and disability by cause 1990-2020: Global Burden of Disease Study. Lancet. 1997;349:1498504. [cited 2017 Nov 26] Available from: http://www.ncbi.nIm.nih.gov/ pubmed/9167458.

44. Fleg JL, Strait J. Age-associated changes in cardiovascular structure and function: a fertile milieu for future disease. Heart Fail Rev. 2012;17:545-54.
[Internet]. NIH Public Access; [cited 2017 Apr 18]Available from: http://www. ncbi.nlm.nih.gov/pubmed/21809160

45. Chung E, Diffee GM. Effect of aging on power output properties in rat skinned cardiac myocytes. J Gerontol A Biol Sci Med Sci. 2011;66:1267-73. [cited 2017 Apr 18] Available from: http://www.ncbi.nlm.nih.gov/pubmed/ 21896503

46. Lakatta EG, Wang M, Najjar SS. Arterial Aging and Subclinical Arterial Disease are Fundamentally Intertwined at Macroscopic and Molecular Levels. Med Clin North Am. 2009;93:583-604. [cited 2017 Apr 18] Available from: http:// www.ncbi.nlm.nih.gov/pubmed/19427493

47. Waller BF. The old-age heart: normal aging changes which can produce or mimic cardiac disease. Clin Cardiol. 1988;11:513-7. [cited 2017 Apr 18] Available from: http://www.ncbi.nlm.nih.gov/pubmed/3048829.

48. Sheridan DJ, Kingsbury MP, Flores NA. Regression of left ventricular hypertrophy; what are appropriate therapeutic objectives? Br J Clin Pharmacol. 1999;47:125-30. [cited 2017 Apr 18] Available from: http://www. ncbi.nlm.nih.gov/pubmed/10190646

49. Muller DN, Luft FC. Direct Renin Inhibition with Aliskiren in Hypertension and Target Organ Damage. Clin J Am Soc Nephrol. 2006;1:221-8. [cited 2017 Apr 18] Available from: http://www.ncbi.nlm.nih.gov/pubmed/ 17699210

50. Chae CU, Albert CM, Moorthy MV, Lee I-M, Buring JE. Vitamin E supplementation and the risk of heart failure in women. Circ Heart Fail. 2012;5:176-82. [cited 2017 Apr 25]Available from: http://www.ncbi.nlm.nih. gov/pubmed/22438520.

51. Mozos I, Stoian D, Luca CT. Crosstalk between Vitamins A, B12, D, K, C, and E Status and Arterial Stiffness. Dis Markers. 2017;2017:1-14. Hindawi Publishing Corporation [cited 2017 Apr 21] Available from: https://www. hindawi.com/journals/dm/2017/8784971/

52. Quail MA, Short R, Pandya B, Steeden JA, Khushnood A, Taylor AM, et al. Abnormal Wave Reflections and Left Ventricular Hypertrophy Late After Coarctation of the Aorta Repair. Hypertension. 2017:69:501-9. (Dallas, Tex. 1979). Wolters Kluwer Health [cited 2017 Apr 25] Available from: http:// www.ncbi.nlm.nih.gov/pubmed/28115510.

53. Rasool AHG, Rahman ARA, Yuen KH, Wong AR. Arterial compliance and vitamin $E$ blood levels with a self emulsifying preparation of tocotrienol rich vitamin E. Arch Pharm Res. 2008;31:1212-7. [cited 2016 Jun 22] Available from: http://www.ncbi.nlm.nih.gov/pubmed/18806966

54. Rasool AHG, Rehman A, Wan Yusuf WN, ARA R. Vitamin E and its effect on arterial stiffness in postmenopausal women-a randomized controlled trial. Int J Clin Pharmacol Ther. 2003;41:587-92. [cited 2017 Apr 21] Available from: http://www.ncbi.nlm.nih.gov/pubmed/14692708

55. Puzianowska-Kuźnicka M, Owczarz M, Wieczorowska-Tobis K, Nadrowski P, Chudek J, Slusarczyk P, et al. Interleukin-6 and C-reactive protein, successful aging, and mortality: the PolSenior study. Immun Ageing. 2016;13:21. [cited 2017 may 31] Available from: http://www.ncbinlm.nih.gov/pubmed/ 27274758

56. Velissaris D, Pantzaris N, Koniari I, Koutsogiannis N, Karamouzos V, Kotroni I, et al. C-Reactive Protein and Frailty in the Elderly: A Literature Review. J Clin Med Res. 2017;9:461-5. Elmer Press; [cited 2017 may 31] Available from: http://www.ncbi.nlm.nih.gov/pubmed/28496545

57. Mackiewicz A, Speroff T, Ganapathi MK, Kushner I. Effects of cytokine combinations on acute phase protein production in two human hepatoma cell lines. J Immunol. 1991;146:3032-7. [cited 2017 may 31] Available from: http://www.ncbi.nlm.nih.gov/pubmed/1707930

58. Parrinello CM, Lutsey PL, Ballantyne CM, Folsom AR, Pankow JS, Selvin E. Sixyear change in high-sensitivity C-reactive protein and risk of diabetes, cardiovascular disease, and mortality. Am Heart J. 2015;170:380-389.e4. [cited 2017 may 31] Available from: http://www.ncbi.nlm.nih.gov/pubmed/ 26299237

59. Prasad K. Tocotrienols and cardiovascular health. Curr Pharm Des. 2011;17: 2147-54. [cited 2017 may 31] Available from: http://www.ncbinlm.nih.gov/ pubmed/21774782.

60. Choi J-H, Do Y, Cheong C, Koh H, Boscardin SB, Oh Y-S, et al. Identification of antigen-presenting dendritic cells in mouse aorta and cardiac valves. J Exp Med. 2009;206:497-505. [cited 2017 May 29] Available from: http:// www.jem.org/lookup/doi/10.1084/jem.20082129.

61. Bönner F, Borg N, Burghoff S, Schrader J. Resident cardiac immune cells and expression of the ectonucleotidase enzymes CD39 and CD73 after ischemic injury. Eltzschig HK, editor. PLoS One. 2012;7:e34730. [cited 2017 May 29] Available from: http://dx.plos.org/10.1371/journal.pone.0034730. 
62. Pinto AR, Paolicelli R, Salimova E, Gospocic J, Slonimsky E, Bilbao-Cortes D, et al. An Abundant Tissue Macrophage Population in the Adult Murine Heart with a Distinct Alternatively-Activated Macrophage Profile. Boone DL, editor. PLoS One. 2012 ;7:e36814. [cited 2017 may 29] Available from: http:// www.ncbi.nlm.nih.gov/pubmed/22590615.

63. Epelman S, Lavine KJ, Beaudin AE, Sojka DK, Carrero JA, Calderon B, et al. Embryonic and adult-derived resident cardiac macrophages are maintained through distinct mechanisms at steady state and during inflammation. Immunity. 2014;40:91-104. [cited 2017 May 29] Available from: http:// linkinghub.elsevier.com/retrieve/pii/S107476131300558X.

64. Ramos GC, van den Berg A, Nunes-Silva V, Weirather J, Peters L, Burkard M, et al. Myocardial aging as a T-cell-mediated phenomenon. Proc Natl Acad Sci. 2017;114:E2420-9. [cited 2017 may 25] Available from: http://www.ncbi. nlm.nih.gov/pubmed/28255084

65. Wilankar C, Sharma D, Checker R, Khan NM, Patwardhan R, Patil A, et al. Role of immunoregulatory transcription factors in differential immunomodulatory effects of tocotrienols. Free Radic Biol Med. 2011;51:129-43. [cited 2017 may 31] Available from: http://www.ncbi.nlm.nih.gov/pubmed/21536125

66. Qureshi AA, Sami SA, Salser WA, Khan FA. Dose-dependent suppression of serum cholesterol by tocotrienol-rich fraction (TRF25) of rice bran in hypercholesterolemic humans. Atherosclerosis. 2002;161:199-207. [cited 2015 Sep 15] Available from: http://www.ncbi.nlm.nih.gov/pubmed/ 11882333

67. Burdeos GC, Nakagawa K, Watanabe A, Kimura F, Miyazawa T. $y$-Tocotrienol attenuates triglyceride through effect on lipogenic gene expressions in mouse hepatocellular carcinoma Hepa 1-6. J Nutr Sci Vitaminol (Tokyo). 2013:59:148-51. [cited 2017 Apr 25] Available from: http://www.ncbi.nlm.nih. gov/pubmed/23727646

68. Pearce BC, Parker RA, Deason ME, Qureshi AA, Wright JJ. Hypocholesterolemic activity of synthetic and natural tocotrienols. J Med Chem. 1992;35:3595-606. [cited 2015 Sep 15] Available from: http://www. ncbi.nlm.nih.gov/pubmed/1433170

69. Swerdlow DI, Preiss D, Kuchenbaecker KB, Holmes MV, Engmann JEL, Shah $T$, et al. HMG-coenzyme A reductase inhibition, type 2 diabetes, and bodyweight: evidence from genetic analysis and randomised trials. Lancet. 2015;385:351-61. [cited 2015 Jul 16] Available from: http://www. pubmedcentral.nih.gov/articlerender.fcgi?artid=4322187\&tool= pmcentrez\&rendertype $=$ abstract

70. Oesterle A, Laufs U, Liao JK. Pleiotropic Effects of Statins on the Cardiovascular System. Circ Res. 2017:120, 229-43. [cited 2017 Feb 21] Available from: http://www.ncbi.nlm.nih.gov/pubmed/28057795

71. Sakamoto K, Kimura J. Mechanism of statin-induced rhabdomyolysis. J Pharmacol Sci. 2013;123:289-94. [cited 2017 mar 7] Available from: http:// www.ncbi.nlm.nih.gov/pubmed/24257439

72. Jones M, Tett S, Peeters GMEE, Mishra GD, Dobson A. New-Onset Diabetes After Statin Exposure in Elderly Women: The Australian Longitudinal Study on Women's Health. Drugs Aging. 2017;34:203-9. [cited 2017 mar 3] Available from: http://www.ncbi.nlm.nih.gov/pubmed/28138911.

73. Lee J, Noh Y, Shin S, Lim H-S, Park RW, Bae SK, et al. Impact of statins on risk of new onset diabetes mellitus: a population-based cohort study using the Korean National Health Insurance claims database. Ther Clin Risk Manag. 2016;12:1533-43. [cited 2017 mar 6] Available from: http://www.ncbi.nlm. nih.gov/pubmed/27785041

74. Chia LL, Jantan I, Chua KH, Lam KW, Rullah K, Aluwi MFM. Effects of Tocotrienols on Insulin Secretion-Associated Genes Expression of Rat Pancreatic Islets in a Dynamic Culture. Front Pharmacol. 2016;7:1-17. Available from: http://journal.frontiersin.org/Article/10.3389/fphar.2016. 00291/abstract.

75. Fang F, Kang Z, Wong C. Vitamin E tocotrienols improve insulin sensitivity through activating peroxisome proliferator-activated receptors. Mol Nutr Food Res. 2010;54:345-52. [cited 2017 mar 6] Available from: http://www. ncbi.nlm.nih.gov/pubmed/19866471.

76. Meigs TE, Simoni RD. Farnesol as a Regulator of HMG-CoA Reductase Degradation: Characterization and Role of Farnesyl Pyrophosphatase. Arch Biochem Biophys. 1997;345:1-9. [cited 2017 mar 6] Available from: http:// www.ncbi.nlm.nih.gov/pubmed/9281305

77. Meigs TE, Roseman DS, Simoni RD. Regulation of 3-hydroxy-3 methylglutaryl-coenzyme A reductase degradation by the nonsterol mevalonate metabolite farnesol in vivo. J Biol Chem. 1996:271, 7916-7222. [cited 2017 mar 6] Available from: http://www.ncbi.nlm.nih.gov/pubmed/ 8626470
78. Qureshi AA, Bradlow BA, Brace L, Manganello J, Peterson DM, Pearce BC, et al. Response of hypercholesterolemic subjects to administration of tocotrienols. Lipids. 1995;30:1171-7. [cited 2015 Sep 15] Available from: http://www.ncbi.nlm.nih.gov/pubmed/8614309

79. Qureshi AA, Qureshi N, Wright JJ, Shen Z, Kramer G, Gapor A, et al. Lowering of serum cholesterol in hypercholesterolemic humans by tocotrienols (palmvitee). Am J Clin Nutr. 1991;53:1021S-6S. [cited 2015 Sep 15] Available from: http://www.ncbi.nlm.nih.gov/pubmed/2012010

80. Qureshi AA, Sami SA, Salser WA, Khan FA. Synergistic effect of tocotrienolrich fraction (TRF(25)) of rice bran and lovastatin on lipid parameters in hypercholesterolemic humans. J Nutr Biochem. 2001;12:318-29. [cited 2015 Sep 15] Available from: http://www.ncbi.nlm.nih.gov/pubmed/11516635.

81. Raederstorff D, Elste V, Aebischer C, Weber P. Effect of either gammatocotrienol or a tocotrienol mixture on the plasma lipid profile in hamsters. Ann Nutr Metab. 2002;46:17-23. [cited 2016 Feb 1]Available from: http:// www.ncbi.nlm.nih.gov/pubmed/11914511.

82. Baliarsingh $\mathrm{S}, \mathrm{Beg} \mathrm{ZH}$, Ahmad J. The therapeutic impacts of tocotrienols in type 2 diabetic patients with hyperlipidemia. Atherosclerosis. 2005;182:36774. [cited 2016 Feb 1] Available from: http://www.ncbi.nlm.nih.gov/ pubmed/16159610

83. Mensink RP, van Houwelingen AC, Kromhout D, Hornstra G. A vitamin E concentrate rich in tocotrienols had no effect on serum lipids, lipoproteins, or platelet function in men with mildly elevated serum lipid concentrations. Am J Clin Nutr. 1999:69:213-9. [cited 2015 Sep 15] Available from: http:// www.ncbi.nlm.nih.gov/pubmed/9989682

84. Wahlqvist ML, Krivokuca-Bogetic Z, Lo CS, Hage B, Smith R, Lukito W. Differential serum responses of tocopherols and tocotrienols during vitamin supplementation in hypercholesterolaemic individuals without change in coronary risk factors. Nutr Res. 1992;12:S181-201. [cited 2015 Sep 15] Available from: http://www.nrjournal.com/article/S0271531705804634/ fulltext.

85. Mustad VA, Smith CA, Ruey PP, Edens NK, DeMichele SJ. Supplementation with 3 compositionally different tocotrienol supplements does not improve cardiovascular disease risk factors in men and women with hypercholesterolemia. Am J Clin Nutr. 2002 76:1237-1243. [cited 2016 Feb 2]; Available from: http://www.ncbi.nlm.nih.gov/pubmed/12450888.

86. Fukagawa NK, Bandini LG, Dietz WH, Young JB. Effect of Age on Body Water and Resting Metabolic Rate. J Gerontol Med Sci. 1996;5:7-73. [cited 2017 Mar 7] Available from: https://www.ncbi.nlm.nih.gov/pubmed/8612106.

87. Psota T, Chen KY. Measuring energy expenditure in clinical populations: rewards and challenges. Eur J Clin Nutr. 2013;67:436-42. [cited 2017 mar 7] Available from: http://www.ncbi.nlm.nih.gov/pubmed/23443826

88. Qureshi AA, Sami SA, Salser WA, Khan FA. Synergistic effect of tocotrienolrich fraction (TRF(25)) of rice bran and lovastatin on lipid parameters in hypercholesterolemic humans. J Nutr Biochem. 2001;12:318-29. [cited 2017 Nov 24] Available from: http://www.ncbi.nlm.nih.gov/pubmed/11516635.

89. McAnally JA, Gupta J, Sodhani S, Bravo L, Mo H. Tocotrienols potentiate lovastatin-mediated growth suppression in vitro and in vivo. Exp Biol Med (Maywood). 2007;232:523-31. [cited 2017 Nov 26] Available from: http:// www.ncbi.nlm.nih.gov/pubmed/17392488

90. Mo H, Elson CE. Studies of the isoprenoid-mediated inhibition of mevalonate synthesis applied to cancer chemotherapy and chemoprevention. Exp Biol Med (Maywood). 2004;229:567-85. [cited 2017 Nov 26] Available from: http://www.ncbi.n/m.nih.gov/pubmed/15229351.

91. Valastyan S, Thakur V, Johnson A, Kumar K, Manor D. Novel transcriptional activities of vitamin $\mathrm{E}$ : inhibition of cholesterol biosynthesis. Biochemistry. 2008;47:744-52. [cited 2017 mar 7] Available from: http://www.ncbi.nlm.nih. gov/pubmed/18095660.

92. Qureshi AA, Pearce BC, Nor RM, Gapor A, Peterson DM, Elson CE. Dietary alpha-tocopherol attenuates the impact of gamma-tocotrienol on hepatic 3-hydroxy-3-methylglutaryl coenzyme A reductase activity in chickens. J Nutr. 1996;126:389-94. [cited 2015 Sep 15] Available from: http://www.ncbi. nlm.nih.gov/pubmed/8632210.

93. Hun Teik K, Theng Theng N, Rajendran R. Dose-Dependent Cholesterolemic Activity of Tocotrienols and a-Tocopherol. Malays J Nutr. 2002;8:157-66. [cited 2017 Mar 7] Available from: http://psasir.upm.edu.my/7097/1/mjn8n2_art3.pdf.

94. Shibata A, Kawakami Y, Kimura T, Miyazawa T, Nakagawa K. a-Tocopherol Attenuates the Triglyceride- and Cholesterol-Lowering Effects of Rice Bran Tocotrienol in Rats Fed a Western Diet. J Agric Food Chem. 2016;64:5361-6. [cited 2017 mar 7] Available from: http://www.ncbi.nlm.nih.gov/pubmed/ 27295311 
95. Leonard SW, Joss JD, Mustacich DJ, Blatt DH, Lee YS, Traber MG. Effects of vitamin $\mathrm{E}$ on cholesterol levels of hypercholesterolemic patients receiving statins. Am J Heal Pharm. 2007;64:2257-66. [cited 2017 mar 7]; Available from: http://www.ncbi.n/m.nih.gov/pubmed/17959578

96. Yuen KH, Wong JW, Lim AB, Ng BH, Choy WP. Effect of Mixed-Tocotrienols in Hypercholesterolemic Subjects. Funct Foods Heal Dis. 2011;1:106-17. [cited 2015 Sep 15] Available from: http://ffhdj.com/index.php/ffhd/article/ view/136/278

97. Siti HN, Kamisah Y, Kamsiah J. The role of oxidative stress, antioxidants and vascular inflammation in cardiovascular disease (a review). Vasc Pharmacol. 2015;71:40-56. Available from: http://www.ncbi.nlm.nih.gov/pubmed/ 25869516

98. Packard RRS, Libby P. Inflammation in atherosclerosis: from vascular biology to biomarker discovery and risk prediction. Clin Chem. 2008;54:24-38. [cited 2015 Nov 10] Available from: http://www.clinchem.org/content/54/1/24.full.

99. Surmi BK, Hasty AH. Macrophage infiltration into adipose tissue: initiation, propagation and remodeling. Futur Lipidol. 2008;3:545-56. [cited 2012 Dec 3] Available from: http://www.pubmedcentral.nih.gov/articlerender. fcgi?artid=2575346\&tool=pmcentrez\&rendertype=abstract

100. Jankovic N, Geelen A, Streppel MT, de Groot LC, Kiefte-de Jong JC, Orfanos $P$, et al. WHO guidelines for a healthy diet and mortality from cardiovascular disease in European and American elderly: the CHANCES project. Am J Clin Nutr. 2015;102:745-56. [cited 2016 Jan 27] Available from: http://www. pubmedcentral.nih.gov/articlerender.fcgi?artid=4588736\&tool= pmcentrez\&rendertype=abstract

101. Kamat JP, TP D. Tocotrienols from palm oil as potent inhibitors of lipid peroxidation and protein oxidation in rat brain mitochondria. Neurosci Lett. 1995;195:179-82.

102. Palozza P, Verdecchia S, Avanzi L, Vertuani S, Serini S, lannone A, et al. Comparative antioxidant activity of tocotrienols and the novel chromanylpolyisoprenyl molecule FeAox-6 in isolated membranes and intact cells. Mol Cell Biochem. 2006;287:21-32.

103. Theriault A, Chao JT, Gapor A. Tocotrienol is the most effective vitamin E for reducing endothelial expression of adhesion molecules and adhesion to monocytes. Atherosclerosis. 2002;160:21-30.

104. Muid S, Anisah Froemming GR, Rahman T, Manaf Ali A, Nawawi HM. Deltaand gamma-tocotrienol isomers are potent in inhibiting inflammation and endothelial activation in stimulated human endothelial cells. Food Nutr Res. 2016;60:1-11.

105. Naito Y, Shimozawa M, Kuroda M, Nakabe N, Manabe H, Katada K, et al. Tocotrienols reduce 25 -hydroxycholesterol-induced monocyte-endothelial cell interaction by inhibiting the surface expression of adhesion molecules. Atherosclerosis. 2005;180:19-25.

106. Li F, Tan W, Kang Z, Wong CW. Tocotrienol enriched palm oil prevents atherosclerosis through modulating the activities of peroxisome proliferators-activated receptors. Atherosclerosis. 2010;211:278-82. Available from: https://doi.org/10.1016/j.atherosclerosis.2010.01.015

107. KALIORA A, Dedoussis GV. Natural antioxidant compounds in risk factors for CVD. Pharmacol Res. 2007;56:99-109. [cited 2017 mar 8] Available from: http://www.ncbi.nlm.nih.gov/pubmed/17572098

108. Harvey A, Montezano AC, Touyz RM. Vascular biology of ageing_Implications in hypertension. J Mol Cell Cardiol. $2015 ; 83: 112-121$. [cited 2017 mar 9] Available from: http://www.ncbi.nlm.nih.gov/pubmed/ 25896391.

109. ALLHAT Officers and Coordinators for the ALLHAT Collaborative Research Group. The Antihypertensive and Lipid-Lowering Treatment to Prevent Heart Attack Trial. Major outcomes in high-risk hypertensive patients randomized to angiotensin-converting enzyme inhibitor or calcium channel blocker vs diuretic: The Antihypertensive and LipidLowering Treatment to Prevent Heart Attack Trial (ALLHAT). JAMA. 2002; 288:2981-97. [cited 2017 Mar 9] Available from: http://www.ncbi.nlm.nih. gov/pubmed/12479763

110. CVS R. Beta-Blockers in Hypertension. Am J Cardiol. 2010;106:1819-25. [cited 2017 mar 9] Available from: http://www.ncbi.nlm.nih.gov/pubmed/21126627

111. Steenen SA, van Wijk AJ, van der Heijden GJ, van Westrhenen R, de Lange J, de Jongh A. Propranolol for the treatment of anxiety disorders: Systematic review and meta-analysis. J Psychopharmacol. 2016;30:128-39. [cited 2017 mar 9] Available from: http://www.ncbi.n/m.nih.gov/pubmed/26487439.

112. Ekbom T, Linjer E, Hedner T, Lanke J, de Faire U, Wester P-O, et al. Cardiovascular events in elderly patients with isolated systolic hypertension. A subgroup analysis of treatment strategies in STOP-Hypertension-2. Blood
Press. 2004;13:137-41. [cited 2017 mar 9] Available from: http://www.ncbi. nlm.nih.gov/pubmed/15223721.

113. Wink K. Are beta-blockers efficacious as first-line therapy for hypertension in the elderly? Curr Hypertens Rep. 2003;5:221-4. [cited 2017 mar 9] Available from: http://www.ncbi.nlm.nih.gov/pubmed/12724054

114. Nishida Y, Takahashi Y, Nakayama T, Asai S. Comparative effect of angiotensin II type I receptor blockers and calcium channel blockers on laboratory parameters in hypertensive patients with type 2 diabetes. Cardiovasc Diabetol. 2012;11:53. [cited 2017 mar 9] Available from: http:// www.ncbi.nlm.nih.gov/pubmed/22594344

115. Sindone A, Erlich J, Lee C, Newman H, Suranyi M, Roger SD. Cardiovascular risk reduction in hypertension: angiotensin-converting enzyme inhibitors, angiotensin receptor blockers. Where are we up to? Intern Med J. 2016;46: 364-72. [cited 2017 mar 9] Available from: http://www.ncbi.nlm.nih.gov/ pubmed/26968600.

116. Jeffers BW, Robbins J, Bhambri R. Efficacy of Calcium Channel Blockers Versus Other Classes of Antihypertensive Medication in the Treatment of Hypertensive Patients With Previous Stroke and/or Coronary Artery Disease. Am J Ther. 2017;24:e68-80. [cited 2017 mar 9] Available from: http://www. ncbi.n/m.nih.gov/pubmed/26588586.

117. Magid DJ, Shetterly SM, Margolis KL, Tavel HM, O'Connor PJ, Selby JV, et al. Comparative Effectiveness of Angiotensin-Converting Enzyme Inhibitors Versus -Blockers as Second-Line Therapy for Hypertension. Circ Cardiovasc Qual Outcomes. 2010;3:453-8. Available from: http://www.ncbi.nlm.nih.gov/ pubmed/20716714

118. Chen N, Zhou M, Yang M, Guo J, Zhu C, Yang J, et al. Calcium channel blockers versus other classes of drugs for hypertension. In: He L, editor. Cochrane database Syst. Rev. Chichester: John Wiley \& Sons, Itd; 2010. p. CD003654. [cited 2017 mar 9]Available from: http://www.ncbi.nlm.nih. gov/pubmed/20687074.

119. Kuti EL, Baker WL, White MC. The development of new-onset type 2 diabetes associated with choosing a calcium channel blocker compared to a diuretic or beta-blocker. Curr Med Res Opin. 2007;23:1239-44. [cited 2017 mar 9] Available from: http://www.ncbi.n/m.nih.gov/ pubmed/17559720.

120. Preston Mason R. Pleiotropic Effects of Calcium Channel Blockers. Curr Hypertens Rep. 2012;14:293-303. [cited 2017 mar 9] Available from: http://www.ncbi.nlm.nih.gov/pubmed/22610475

121. Sacks FM, Obarzanek E, Windhauser MM, Svetkey LP, Vollmer WM, McCullough M, et al. Rationale and design of the Dietary Approaches to Stop Hypertension trial (DASH). A multicenter controlled-feeding study of dietary patterns to lower blood pressure. Ann Epidemiol. 1995; 5:108-18. [cited 2017 mar 9] Available from: http://www.ncbi.nlm.nih. gov/pubmed/7795829.

122. Muharis SP, Top AGM, Murugan D, Mustafa MR. Palm oil tocotrienol fractions restore endothelium dependent relaxation in aortic rings of streptozotocin-induced diabetic and spontaneously hypertensive rats. Nutr Res. 2010;30:209-16. [cited 2016 Feb 2]; Available from: http:// www.ncbi.nlm.nih.gov/pubmed/20417882

123. Ali SF, Nguyen JCD, Jenkins TA, Woodman OL. Tocotrienol-Rich Tocomin Attenuates Oxidative Stress and Improves Endothelium-Dependent Relaxation in Aortae from Rats Fed a High-Fat Western Diet. Front Cardiovasc Med. 2016;3:39. [cited 2017 mar 9] Available from: http://www.ncbi.nlm.nih.gov/pubmed/27800483

124. Cobley JN, McHardy H, Morton JP, Nikolaidis MG, Close GL. Influence of vitamin $\mathrm{C}$ and vitamin $\mathrm{E}$ on redox signaling: Implications for exercise adaptations. Free Radic Biol Med. 2015;84:65-76. [cited 2015 may 14] Available from: http://www.ncbi.nlm.nih.gov/pubmed/25841784.

125. Aiguo Wu A, Zhe Ying Z, Gomez-Pinilla F. Vitamin E protects against oxidative damage and learning disability after mild traumatic brain injury in rats. Neurorehabil. Neural Repair. 2010;24:-290, 8. [cited 2016 Dec 21]Available from: http://www.ncbi.nlm.nih.gov/pubmed/19841436

126. Murdolo G, Piroddi M, Luchetti F, Tortoioli C, Canonico B, Zerbinati C, et al. Oxidative stress and lipid peroxidation by-products at the crossroad between adipose organ dysregulation and obesity-linked insulin resistance. Biochimie. 2013;95:585-594. Available from: doi:https://doi.org/10.1016/j. biochi.2012.12.014

127. Pashkow FJ, Watumull DG, Campbell CL. Astaxanthin: a novel potential treatment for oxidative stress and inflammation in cardiovascular disease. Am J Cardiol. 2008;101:S58-68. Available from: http://www.sciencedirect. com/science/article/pii/S0002914908002191. 
128. Fan Q, Chen L, Cheng S, Li F, Lau WB, Wang LF, et al. Aging aggravates nitrate-mediated ROS/RNS changes. Oxid Med Cell Longev Hindawi Publishing Corporation; 2014;2014.

129. Serbinova E, Kagan V, Han D, Packer L. Free radical recycling and intramembrane mobility in the antioxidant properties of alpha-tocopherol and alpha-tocotrienol. Free Radic Biol Med. 1991;10:263-75. [cited 2016 Feb 3] Available from: http://www.ncbi.nlm.nih.gov/pubmed/1649783

130. Lakshmi SW, Naushad SM, Reddy CA, Saumya K, Rao DS, Kotamraju S, et al. Oxidative stress in coronary artery disease: epigenetic perspective. Mol Cell Biochem. 2013;374:203-11.

131. Dusting GJ, Triggle C. Are we over oxidized? Oxidative stress, cardiovascular disease, and the future of intervention studies with antioxidants. Vasc Health Risk Manag. 2005;1:93-7. [cited 2016 Nov 22]; Available from: http:// www.ncbi.nlm.nih.gov/pubmed/17315394

132. Ohira T, Iso H. Cardiovascular Disease Epidemiology in Asia - An Overview. Circ J. 2013;77:1646-52. [cited 2015 Nov 24] Available from: http://www. ncbi.nlm.nih.gov/pubmed/23803294

133. Vichova T, Motovska Z. Oxidative stress: Predictive marker for coronary artery disease. Exp Clin Cardiol. 2013;18:e88-91. [cited 2017 Apr 18] Available from: http://www.ncbi.nlm.nih.gov/pubmed/23940453

134. Feng Y, Shen C, Ma G, Wang J, Chen Z, Dai Q, et al. Prolonged pain to hospital time is associated with increased plasma advanced oxidation protein products and poor prognosis in patients with percutaneous coronary intervention for ST-elevation myocardial infarction. Heart Vessel. 2010;25:374-8. [cited 2017 Apr 18] Available from: http://link.springer.com/ 10.1007/s00380-009-1220-8.

135. Hokamaki J, Kawano H, Soejima H, Miyamoto S, Kajiwara I, Kojima S, et al. Plasma thioredoxin levels in patients with unstable angina. Int J Cardiol. 2005;99:225-31. [cited 2017 Apr 18] Available from: http://www.ncbi.nlm.nih. gov/pubmed/15749180

136. Keith M, Geranmayegan A, Sole MJ, Kurian R, Robinson A, Omran AS, et al. Increased oxidative stress in patients with congestive heart failure. J Am Coll Cardiol. 1998;31:1352-6. [cited 2017 Apr 18] Available from: http://www.ncbi.n/m.nih.gov/pubmed/9581732

137. Jekell A, Hossain A, Alehagen U, Dahlström U, Rosén A. Elevated circulating levels of thioredoxin and stress in chronic heart failure. Eur J Heart Fail. 2004;6:883-90. [cited 2017 Apr 18] Available from: http://www.ncbi.nlm.nih. gov/pubmed/15556050.

138. de Meirelles LR, de Resende AC, Matsuura C, Salgado Â, Pereira NR, Cascarelli $P G$, et al. Platelet activation, oxidative stress and overexpression of inducible nitric oxide synthase in moderate heart failure. Clin Exp Pharmacol Physiol. 2011;38:705-10. [cited 2017 Apr 18] Available from: http://www. ncbi.nlm.nih.gov/pubmed/21806669

139. Munzel T, Sayegh H, Freeman BA, Tarpey MM, Harrison DG. Evidence for enhanced vascular superoxide anion production in nitrate tolerance. J Clin Invest. 1995;95:187-94

140. Das M, Das S, Wang P, Powell SR, Das DK. Caveolin and proteasome in tocotrienol mediated myocardial protection. Cell Physiol Biochem. 2008; 22:287-94. [cited 2016 Feb 4] Available from: http://www. pubmedcentral.nih.gov/articlerender.fcgi?artid=2929803\&tool= pmcentrez\&rendertype=abstract

141. Qureshi AA, Tan X, Reis JC, Badr MZ, Papasian CJ, Morrison DC, et al. Suppression of nitric oxide induction and pro-inflammatory cytokines by novel proteasome inhibitors in various experimental models. Lipids Health Dis. 2011;10:177. Available from: http://www.pubmedcentral.nih.gov/ articlerender.fcgi?artid=3206449\&tool=pmcentrez\&rendertype=abstract.

142. Oliva J, French SW, Li J, Bardag-Gorce F. Proteasome inhibitor treatment reduced fatty acid, triacylglycerol and cholesterol synthesis. Exp Mol Pathol. 2012;93:26-34. [cited 2012 Apr 30] Available from: http://www.ncbi.nlm.nih. gov/pubmed/22445925

143. Polymeropoulos E, Bagos P, Papadimitriou M, Rizos I, Patsouris E, Toumpoulis I. Vitamin C for the Prevention of Postoperative Atrial Fibrillation after Cardiac Surgery: A Meta-Analysis. Adv Pharm Bull. 2016;6: 243-50. [cited 2017 mar 7] Available from: http://www.ncbi.nlm.nih.gov/ pubmed/27478787

144. Rodrigo R, Gutierrez R, Fernandez R, Guzman P. Ageing improves the antioxidant response against postoperative atrial fibrillation: a randomized controlled trial. Interact Cardiovasc Thorac Surg. 2012;15:209-14. [cited 2017 mar 7]; Available from: http://www.ncbi.nlm.nih.gov/pubmed/22561296.

145. Hemilä H, Suonsyrjä T. Vitamin C for preventing atrial fibrillation in high risk patients: a systematic review and meta-analysis. BMC Cardiovasc Disord.
2017;17:49. [cited 2017 mar 7]; Available from: http://www.ncbi.nlm.nih.gov/ pubmed/28143406

146. Hu X, Yuan L, Wang H, Li C, Cai J, Hu Y, et al. Efficacy and safety of vitamin C for atrial fibrillation after cardiac surgery: A meta-analysis with trial sequential analysis of randomized controlled trials. Int J Surg. 2017;37:58-64. [cited 2017 mar 8] Available from: http://www.ncbi.nlm.nih.gov/pubmed/ 27956113

147. Ferro D, Franciosa P, Cangemi R, Carnevale R, Pignatelli $P$, Loffredo $L$, et al. Serum levels of vitamin $\mathrm{E}$ are associated with early recurrence of atrial fibrillation after electric cardioversion. Circ Arrhythm Electrophysiol. 2012;5: 327-33. [cited 2017 Apr 25] Available from: http://circep.ahajournals.org/cgi/ doi/10.1161/CIRCEP.111.968248

148. Crimmins EM. Lifespan and Healthspan: Past, Present, and Promise. Gerontologist. 2015;55:901-11. [cited 2017 mar 8] Available from: http:// www.ncbi.nlm.nih.gov/pubmed/26561272

149. Wongcharoen W, Phrommintikul A. The protective role of curcumin in cardiovascular diseases. Int J Cardiol. 2009;133:145-51. [cited 2017 Nov 4] Available from: http://www.ncbi.n/m.nih.gov/pubmed/19233493

150. Bonnefont-Rousselot D. Resveratrol and Cardiovascular Diseases. Nutrients. 2016;8:250. [cited 2017 Nov 24] Available from: http://www.mdpi.com/2072$6643 / 8 / 5 / 250$

151. Khurana S, Venkataraman K, Hollingsworth A, Piche M, Tai TC. Polyphenols: benefits to the cardiovascular system in health and in aging. Nutrients. 2013;5:3779-827. [cited 2017 Nov 24] Available from: http://www.mdpi.com/ 2072-6643/5/10/3779/

152. Anand P, Kunnumakkara AB, Newman RA, Aggarwal BB. Bioavailability of curcumin: problems and promises. Mol Pharm. 2007;4:807-18. [cited 2017 Nov 24] Available from: http://pubs.acs.org/doi/abs/10.1021/mp700113r

153. Baur JA, Sinclair DA. Therapeutic potential of resveratrol: the in vivo evidence. Nat Rev Drug Discov. 2006;5:493-506. [cited 2017 Nov 24] Available from: http://www.ncbi.nlm.nih.gov/pubmed/16732220

154. Gursoy RN, Benita S. Self-emulsifying drug delivery systems (SEDDS) for improved oral delivery of lipophilic drugs. Biomed Pharmacother. 2004;58: 173-82. [cited 2015 Jun 20] Available from: http://www.ncbi.n/m.nih.gov/ pubmed/15082340.

155. Chouhan N, Mittal V, Kaushik D, Khatkar A, Raina M. Self emulsifying drug delivery system (SEDDS) for phytoconstituents: a review. Curr Drug Deliv. 2015;12:244-53. [cited 2017 Apr 24] Available from: http://www.ncbi.nlm.nih. gov/pubmed/25335929

156. Alqahtani S, Alayoubi A. Enhanced Solubility and Oral Bioavailability of c -Tocotrienol Using a Self-Emulsifying Drug Delivery System ( SEDDS). Lipids. 2014:8:819-29.

157. Springett GM, Husain K, Neuger A, Centeno B, Chen DT, Hutchinson TZ, et al. A phase I safety, pharmacokinetic, and Pharmacodynamic Presurgical trial of vitamin $\mathrm{E} \delta$-tocotrienol in patients with pancreatic ductal neoplasia. EBioMedicine 2015;2:1987-1995. Available from: doi:https://doi.org/10.1016/j. ebiom.2015.11.025

158. Dinarello CA. Anti-inflammatory Agents: Present and Future. Cell. 2010;140 935:-50. [cited 2017 may 31] Available from: http://www.ncbi.nlm.nih.gov/ pubmed/20303881

159. Ma XH, Zheng CJ, Han LY, Xie B, Jia J, Cao ZW, et al. Synergistic therapeutic actions of herbal ingredients and their mechanisms from molecular interaction and network perspectives. Drug Discov Today. 2009;14:579-88. [cited 2017 may 31] Available from: http://www.ncbi.nlm.nih.gov/pubmed/ 19508920

160. Etkin NL. The co-evolution of people, plants, and parasites: biological and cultural adaptations to malaria. Proc Nutr Soc. 2003:62:311-7. [cited 2017 may 31] Available from: http://www.ncbi.nlm.nih.gov/pubmed/14506878. 